\title{
8. MINERAL COMPOSITION OF COARSE-SILT FRACTION OF THE BLACK SEA LATE CENOZOIC SEDIMENTS
}

\author{
E.S. Trimonis and K.M. Shimkus, P.P. Shirshov Institute of Oceanology, \\ USSR Academy of Sciences, Kaliningrad USSR \\ and \\ D.A. Ross, Woods Hole Oceanographic Institution, Woods Hole, Massachusetts
}

\section{INTRODUCTION}

Mineralogical investigations of the coarse-silt fraction $(0.1-0.05 \mathrm{~mm})$ were carried out on samples obtained from Holes 379A, 380, 380A, and 381 (DSDP Leg 42B) with the purpose of determining the source areas of terrigenous material and peculiarities of its distribution in the Black Sea during late Cenozoic time. The coarse-silt fraction was divided into heavy and light subfractions using bromoform (sp. gr. >2.9). Mineralogical analyses were made on immersion slides under polarizing microscope MIN-8, using no less than 300 grains per slide.

The composition of samples studied is given in Tables 1 to 4. Holocene and late Pleistocene deposits in adjacent drilling areas (Figure 1, see also Fig. 1a in Trimonis and Shimkus, this volume), which were studied earlier, are shown in Table 5.

\section{RESULTS}

\section{Hole 379A}

Hole $379 \mathrm{~A}$ is located within the eastern open-sea mineralogical province of the Recent sediments (Trimonis, 1972) where concentrations of pyroxenes, magnetite, ilmenite, muscovite, and weathered minerals occur in the upper layers of the deposits. Upper Quaternary terrigenous turbidites, the mineral composition of which is similar to that of the eastern Anatolian mineralogical province of the Recent sediments, were found at Station 2293 immediately adjacent to Site 379 . Among the heavy clastic minerals, clinopyroxenes are predominant. Blue-green and greenish brown hornblendes, epidotes, and opaque black non-magnetic minerals are of considerable importance; modified rock fragments are common. Authigenic minerals are dominated by iron sulfides.

The light subfraction is made up mainly of modified rock fragments. Carbonates, quartz, and feldspars are abundant, the latter being in a greater abundance than quartz.

The upper part of Hole 379A mainly consists of lowcalcareous silty muds and clays with sandy silt interbeds (Unit 3, Würm). Epidote-zoisite, clinopyroxenes, and hornblendes dominate over heavy clastic minerals in the unit, more often epidote-zoisite or clinopyroxenes being prevalent. In the clayey mud interbed $(6-2,32-38 \mathrm{~cm})$, the epidote-zoisite content makes up $40.6 \%$. It should be noted that such large amounts of epidote-zoisite are not found in modern

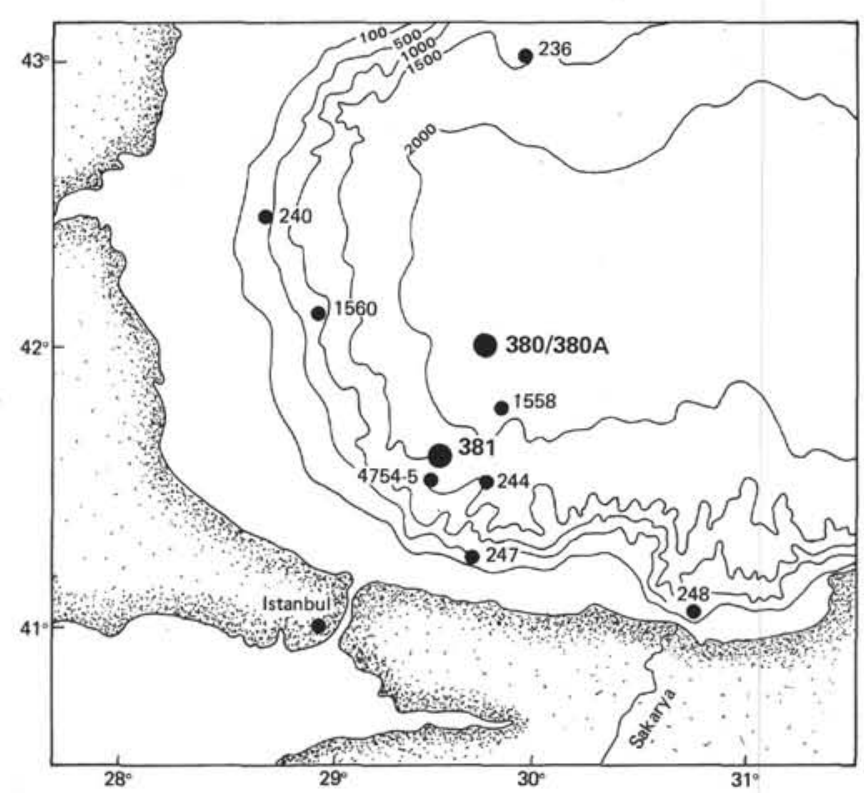

Figure 1. Site location map, DSDP Leg 42B.

river alluvium and Recent deep-sea sediments, indicating the existence of an additional source of these minerals during the last glacial epoch. Increasing content of epidote-zoisite is probably linked with more intensive erosion during glacial time of the central part of the Great Caucasus main ridge. It is composed of gneiss, mica schists, amphibolites, quartz rocks, marbles, etc., which crop out as a wide band along the ridge watershed in river heads of the Belaya, the Great Laba, and the Great Zelenchuk (Paffengoltz, 1959). The Crimea metamorphic series also may have contributed. Sample $1-2,70-78 \mathrm{~cm}$, is decidedly different, where micas (chlorite, muscovite, biotite) are of primary importance and decreased amounts of clastic minerals and a great abundance of authigenic sulfides (41.4\%) occur. Judging by associations of heavy minerals in Unit 3 , the sediments were derived both from the western and eastern Anatolian provinces, but more abundantly and more often from the latter. Some interbeds were formed from clastic material transported from the Caucasian drainage area and, possibly, from the Crimea, as evidenced by their high chlorite and mica content.

The light subfraction part of Unit 3 consists chiefly of weathered rock fragments (their quantity amounting sometimes up to $50 \%$ ), quartz, and feldspars. The mica and quartz abundance is most often sometimes more 
TABLE 1A

Mineral Composition of Heavy (sp.w. $>2.9$ ) Subfraction 0.1-0.05 mm in Bottom Sediments of Hole 379A (Leg 42B)

\begin{tabular}{|c|c|c|c|c|c|c|c|c|c|c|c|c|c|c|c|c|}
\hline $\begin{array}{c}\text { Sample } \\
\text { (Interval in } \mathrm{cm} \text { ) }\end{array}$ & $\begin{array}{c}\text { Content } \\
\text { of } \\
\text { Heavy } \\
\text { Subfraction } \\
(\%)\end{array}$ & 1 & 2 & 3 & 4 & 5 & 6 & 7 & 8 & 9 & 10 & 11 & 12 & 13 & 14 & 15 \\
\hline $1-2,70-78$ & 1.7 & 0.4 & 0.4 & 31.9 & 3.0 & - & - & 3.0 & 1.1 & 5.9 & 7.4 & - & - & - & - & - \\
\hline $4-3.30-40$ & 2.8 & 10.3 & 1.2 & 9.0 & 10.6 & - & 0.2 & 18.2 & 0.2 & 3.3 & - & 0.2 & 0.6 & 0.1 & - & 0.2 \\
\hline $4-5,125$ & 8.8 & 15.6 & 1.8 & 6.1 & 17.3 & - & - & 12.7 & 0.6 & 2.4 & - & - & 0.6 & - & - & - \\
\hline $6-2,32-38$ & 2.0 & 13.2 & 1.3 & 7.8 & 10.7 & - & 0.2 & 40.6 & 0.5 & 5.8 & 0.2 & 0.2 & 0.2 & 0.2 & - & 0.2 \\
\hline $6-5,36-46$ & 3.5 & 12.3 & 0.6 & 5.0 & 11.2 & - & - & 21.4 & 0.4 & 3.6 & 0.2 & - & 0.2 & - & - & - \\
\hline $7-2,20-30$ & 4.6 & 9.2 & 1.0 & 9.3 & 4.2 & 0.1 & 0.1 & 20.0 & 0.3 & 2.2 & - & - & 0.1 & - & - & 0.3 \\
\hline $8-4,14-16$ & 0.9 & 9.2 & 0.9 & 5.9 & 22.1 & - & 0.2 & 36.1 & 3.7 & 3.9 & 0.2 & 0.2 & 0.4 & 0.2 & - & 0.2 \\
\hline $9-3,100-108$ & 1.3 & 3.8 & - & 1.1 & 25.4 & 0.2 & - & 16.5 & 3.6 & 4.1 & 0.8 & - & 0.8 & - & - & - \\
\hline $9-5,50-58$ & 3.6 & 6.2 & 0.7 & 0.2 & 27.3 & - & - & 16.6 & 0.5 & 2.7 & 0.2 & 0.5 & 1.2 & 0.2 & - & - \\
\hline $10-1,120-130$ & 2.7 & 1.9 & 0.5 & 2.4 & 15.7 & - & 0.1 & 28.4 & 2.0 & 1.7 & 0.4 & 0.1 & 0.1 & 0.1 & - & - \\
\hline $10-3,85-93$ & 7.7 & 5.5 & 0.9 & 4.1 & 9.7 & 0.2 & - & 23.3 & - & 1.6 & - & - & 0.2 & 0.2 & - & 0.2 \\
\hline $10-5,11-13$ & 1.4 & 0.8 & 0.4 & 1.3 & 31.0 & 0.2 & 0.2 & 22.0 & 1.9 & 7.6 & 1.1 & 0.2 & 0.4 & 0.2 & - & - \\
\hline $11-2,55-64$ & 1.2 & 2.9 & 1.1 & 0.8 & 24.3 & - & 0.2 & 21.6 & 3.9 & 6.2 & 0.4 & 0.2 & 0.2 & 0.2 & - & - . \\
\hline $11-5,77-78$ & 4.2 & 3.0 & - & 6.5 & 10.3 & 0.3 & 0.1 & 29.9 & 0.3 & 5.3 & 0.3 & 0.1 & 0.1 & - & - & - \\
\hline $13-5,1-7$ & 2.9 & 15.8 & 0.7 & 5.8 & 10.2 & 0.3 & - & 23.0 & 0.5 & 5.3 & 0.3 & 0.3 & 0.3 & - & - & - \\
\hline $14-4,0-10$ & 3.5 & 15.0 & 0.2 & 1.8 & 25.2 & 0.6 & - & 18.0 & 1.2 & 2.6 & 0.2 & 0.2 & 0.9 & 0.2 & 0.2 & - \\
\hline $15-2,55-65$ & 1.4 & 15.2 & 0.1 & 7.0 & 9.5 & - & 0.1 & 28.9 & 0.9 & 6.0 & 0.1 & 0.1 & 0.3 & 0.1 & - & - \\
\hline $15-5,2-12$ & 2.5 & 18.2 & 0.2 & 5.7 & 10.1 & - & 0.2 & 26.0 & 0.2 & 2.8 & 0.2 & 0.2 & 0.4 & - & - & - \\
\hline $16-2,50-52$ & 0.9 & 27.8 & 4.8 & 10.0 & 12.6 & - & - & 14.4 & 0.2 & 1.2 & - & 7.6 & 1.5 & - & 0.2 & - \\
\hline $16-3,17-27$ & 0.3 & 20.9 & 6.1 & 0.6 & 12.0 & - & - & 18.0 & - & - & - & 11.2 & 2.6 & - & 0.6 & - \\
\hline $17-1,25-35$ & 3.5 & 8.9 & 0.6 & 0.9 & 34.4 & 0.6 & - & 17.4 & 1.7 & 3.7 & 0.4 & 0.2 & 0.4 & 0.2 & - & - \\
\hline $19-3,84-85$ & 19.2 & 0.4 & - & 1.1 & 0.7 & 0.5 & 0.2 & 1.1 & 0.8 & 1.9 & 3.3 & - & - & - & - & - \\
\hline $19-6,132-134$ & 1.5 & 4.2 & 0.9 & 2.9 & 11.9 & 0.7 & 0.4 & 36.7 & 0.3 & 14.5 & 5.8 & 0.3 & - & 0.3 & 0.3 & 0.9 \\
\hline $20-3,23-25$ & 6.1 & 15.6 & 0.7 & 5.3 & 10.7 & - & - & 24.6 & 0.7 & 4.8 & 0.2 & - & 1.4 & 0.2 & - & - \\
\hline $21-6,0-10$ & 1.2 & 2.9 & 1.5 & 4.2 & 8.2 & 0.5 & 0.5 & 22.9 & 1.9 & 28.0 & 11.8 & 0.3 & - & 0.3 & 0.3 & 0.3 \\
\hline $23-2,0-11$ & 3.3 & 5.2 & - & 43.6 & 7.7 & - & 1.3 & 5.1 & 3.9 & 6.4 & 6.4 & 2.6 & - & - & - & - \\
\hline $23-2,150-158$ & 4.2 & 17.9 & 0.4 & 7.8 & 17.9 & - & - & 31.0 & 0.4 & 1.5 & 0.4 & 0.2 & 0.2 & 0.2 & - & - \\
\hline $25-3,120-121$ & 1.5 & 2.6 & - & - & 3.6 & 0.5 & - & 39.5 & - & 2.0 & - & - & - & - & - & - \\
\hline $25-3,124-125$ & 2.2 & 1.5 & 1.3 & 1.8 & 14.6 & 0.2 & - & 27.5 & 0.6 & 4.4 & - & 0.2 & 0.2 & 0.6 & - & - \\
\hline $25-3,128-129$ & 8.2 & 0.4 & 0.2 & 0.4 & 0.4 & 0.3 & - & 10.1 & 0.2 & 0.6 & - & 0.3 & 0.3 & - & - & - \\
\hline $26-2,27-29$ & 1.2 & 0.4 & 1.2 & 3.3 & 3.7 & 3.5 & 0.3 & 13.8 & 6.2 & 24.2 & 18.0 & - & - & - & - & - \\
\hline $27-5,58-60$ & 1.6 & 3.2 & 0.9 & 10.1 & 5.7 & 1.1 & 0.3 & 14.3 & 1.2 & 29.2 & 9.0 & 0.1 & - & - & - & 0.1 \\
\hline $28-2,24-26$ & 1.1 & 0.8 & 0.7 & 5.6 & 4.7 & - & 0.3 & 12.4 & 1.6 & 27.9 & 22.0 & 0.3 & - & - & 0.3 & - \\
\hline $28-6,74-76$ & 0.7 & 6.2 & 1.3 & 5.6 & 16.0 & - & 0.4 & 51.0 & 1.6 & 5.3 & 1.5 & - & 0.2 & 0.2 & - & 0.4 \\
\hline $28-6,78-80$ & 1.1 & 7.4 & 0.5 & 1.5 & 13.8 & 0.2 & 0.5 & 56.5 & 0.2 & 3.8 & 0.2 & 0.2 & 0.2 & 0.5 & - & 0.2 \\
\hline $29-1,94-96$ & 3.3 & 0.4 & 0.2 & 0.6 & 3.0 & 0.2 & 0.2 & 14.6 & 1.1 & 10.4 & 3.6 & - & - & - & - & - \\
\hline $29-5,98-105$ & 50.0 & 0.5 & - & 2.1 & 0.2 & - & - & 0.2 & - & 1.5 & 0.2 & - & - & - & - & \\
\hline $37-1,84-86$ & 0.4 & 10.1 & 1.0 & 8.3 & 10.8 & 0.2 & 1.2 & 49.4 & 0.6 & 5.0 & 0.8 & - & 0.3 & - & 0.2 & 0.2 \\
\hline $40-2,133-135$ & 0.5 & 9.6 & - & 7.1 & 3.3 & 0.2 & 0.2 & 11.6 & 4.2 & 35.8 & 11.2 & 0.2 & - & - & - & 0.2 \\
\hline $42-3,20-22$ & 7.6 & 0.8 & 0.3 & 1.1 & 1.2 & 0.3 & 0.3 & 1.3 & 0.3 & 0.3 & - & - . & 0.3 & - & - & - \\
\hline $42-3,25-27$ & 1.1 & 2.6 & 0.2 & 1.2 & 13.9 & 0.2 & 0.4 & 32.0 & 0.4 & 7.3 & 3.6 & - & 0.4 & - & 0.2 & 0.2 \\
\hline $46-2,104-106$ & 1.5 & 6.0 & 1.1 & 10.5 & 9.3 & - & 0.8 & 49.0 & 0.4 & 3.1 & 4.1 & 0.3 & 0.8 & 0.3 & - & 0.5 \\
\hline $47-6,106-108$ & 0.9 & 6.3 & 3.1 & 4.4 & 11.5 & 0.4 & 0.4 & 42.8 & 0.8 & 7.4 & 5.3 & - & 0.6 & 0.4 & - & 0.2 \\
\hline $50-3,144-146$ & 16.4 & 0.5 & 0.2 & 23.1 & 0.2 & - & - & 1.6 & 0.5 & 1.3 & 0.8 & - & - & - & - & 0.2 \\
\hline $50-5,12-21$ & 2.1 & 0.4 & 0.2 & 2.2 & 0.9 & - & 0.2 & 4.3 & 2.2 & 19.2 & 7.5 & - & - & 0.2 & - & - \\
\hline $51-2,20-22$ & 1.6 & 2.6 & 0.3 & 17.4 & 10.6 & - & 0.3 & 26.9 & - & 14.5 & 4.5 & - & - & - & - & 0.3 \\
\hline $52-1,55-65$ & 2.0 & 0.8 & 0.1 & 19.0 & 7.6 & 0.3 & 0.1 & 16.1 & 1.2 & 4.9 & 0.6 & - & 0.9 & 0.1 & - & 0.1 \\
\hline $54-2,20-34$ & 0.4 & 6.5 & - & 20.6 & 7.2 & - & 0.3 & 25.8 & 1.1 & 16.8 & 5.8 & - & - & - & - & 0.3 \\
\hline $56-1,18-20$ & 1.2 & 5.4 & 0.5 & 2.6 & 6.7 & - & 0.3 & 64.8 & 0.1 & 3.3 & 1.9 & - & 0.2 & 0.1 & - & 0.3 \\
\hline $58-4,143-145$ & 14.8 & - & 0.2 & 18.6 & 0.9 & - & - & 5.0 & 0.2 & 4.3 & 2.3 & - & 0.2 & - & 0.2 & 0.2 \\
\hline $58-4,145-147$ & 1.0 & - & 0.9 & 4.3 & 9.0 & 0.2 & 0.2 & 15.4 & 2.1 & 16.4 & 6.8 & 0.2 & 0.2 & 0.2 & - & - \\
\hline $67-4,110-120$ & 8.4 & 23.2 & 1.5 & 7.9 & 5.6 & - & - & 23.1 & 0.6 & 0.6 & 0.2 & - & - & - & - & 0.4 \\
\hline $68-5,84-86$ & 2.5 & 17.8 & 1.6 & 5.3 & 13.7 & - & 0.6 & 38.0 & 0.2 & 4.7 & 0.4 & - & 0.8 & - & - & 0.4 \\
\hline
\end{tabular}

Note: 1 , opaque black; 2 , leucoxene; 3 , hydrogoethite; 4 , hornblende (green); 5 , aktinolite-tremolite; 6 , alkalic amphiboles; 7 , group of epidote-zoisite; 8 , biotite; 9 , chlorite; 10 , muscovite; 11 , zircon; 12 , apatite; 13 , sphene; 14 , rutile; 15 , spinel; 16 , garnet; 17 , tourmaline; 18 , staurolite; 19 , chloritoid; 20 , disthene; 21 , sillimanite; 22 , andalusite; 23 , rare (brukite, fluorite); 24 , monoclinic pyroxenes; 25 , orthorhombic pyroxenes; 26 , carbonates; 27 , barite; 28 , flauconite; 29 , sulfides. Cores 1 to 7 - Unit 3 , Würm; Cores

than that of feldspars. Such ratios are characteristic of the pre-Black Sea region (Muller and Stoffers, 1974). As far as biogenic material is concerned, one sample of terrigenous mud $(7-2,20-30 \mathrm{~cm})$ in the light subfraction is characterized by a large content $(43.6 \%)$ of diatoms.

In Riss-Würm deposits (Units 4, 5) the heavy subfraction contents range between wide intervals, from $0.9 \%$ to $7.7 \%$; their maxima are present in coarse silts. Clastic minerals constitute their basic part, but authigenic sulfides, although always present, are of subordinate importance (3\% to $20.5 \%$ ). Hornblendes, epidotes, and clinopyroxenes play a principal role among heavy minerals. Black opaque minerals, hydrogoethite, micas (mainly chlorite and biotite), and 
TABLE 1A - Continued

\begin{tabular}{|c|c|c|c|c|c|c|c|c|c|c|c|c|c|c|}
\hline 16 & 17 & 18 & 19 & 20 & 21 & 22 & 23 & 24 & 25 & 26 & 27 & 28 & 29 & Total $(\%)$ \\
\hline - & - & - & - & - & - & - & - & 0.4 & - & 4.9 & - & - & 41.4 & 99.8 \\
\hline 0.2 & - & 0.2 & - & 0.2 & - & - & - & 30.7 & - & 2.8 & - & - & 12.1 & 100.3 \\
\hline 3.0 & - & - & - & - & - & - & - & 29.6 & 0.3 & 8.2 & - & - & 1.8 & 100.0 \\
\hline 0.5 & 0.5 & - & - & - & 0.2 & - & - & 8.6 & - & 5.8 & - & - & 3.3 & 100.0 \\
\hline 0.6 & - & - & - & - & - & - & - & 35.6 & 0.2 & 7.8 & - & - & 0.9 & 100.0 \\
\hline 0.1 & - & - & - & - & - & - & - & 22.0 & 0.1 & 0.3 & - & - & 30.9 & 100.2 \\
\hline 2.3 & 0.2 & - & - & 0.2 & - & - & - & 7.8 & - & 3.0 & - & - & 3.0 & 99.7 \\
\hline 5.0 & - & - & - & - & - & - & - & 24.4 & 0.5 & 4.7 & - & - & 9.1 & 100.0 \\
\hline 2.5 & - & - & - & - & 0.2 & 0.2 & - & 25.2 & 0.2 & 6.2 & - & - & 9.2 & 100.0 \\
\hline 0.1 & - & - & - & - & - & - & - & 20.6 & - & 5.4 & - & - & 20.5 & 100.0 \\
\hline- & - & - & - & - & - & - & - & 28.4 & 0.2 & 6.0 & - & - & 19.5 & 100.0 \\
\hline 0.2 & 0.2 & 0.2 & - & - & 0.2 & - & - & 14.3 & - & 7.4 & - & - & 10.2 & 100.0 \\
\hline 0.2 & - & - & - & - & - & - & - & 22.7 & - & 4.1 & - & - & 11.1 & 100.0 \\
\hline- & - & - & - & 0.1 & - & - & - & 20.3 & - & 6.3 & - & - & 17.1 & 100.0 \\
\hline 0.7 & - & - & - & 0.3 & - & - & - & 27.0 & 0.3 & 5.3 & - & - & 3.6 & 99.7 \\
\hline 1.8 & 0.2 & 0.2 & - & 0.2 & 0.2 & 0.2 & - & 28.2 & - & 1.2 & - & - & 1.5 & 100.0 \\
\hline 0.1 & 0.1 & - & - & - & 0.1 & - & - & 23.4 & 0.1 & 7.6 & - & - & 0.3 & 100.0 \\
\hline 0.8 & 0.2 & - & - & - & - & - & - & 25.0 & - & 5.6 & - & - & 4.2 & 100.0 \\
\hline 5.5 & 1.5 & 1.2 & - & 0.7 & - & 0.2 & - & 5.3 & - & 3.3 & - & - & 2.0 & 100.0 \\
\hline 13.1 & 1.6 & 1.6 & - & 0.2 & - & 0.2 & - & 4.6 & 3.2 & 3.5 & - & - & - & 100.0 \\
\hline 4.1 & - & - & - & - & - & - & - & 7.5 & - & 6.3 & - & - & 12.6 & 99.9 \\
\hline 0.2 & - & - & - & 0.2 & - & - & 0.2 & 0.2 & 0.2 & 1.1 & - & - & 87.7 & 99.8 \\
\hline 0.3 & 0.3 & - & - & - & - & - & - & 0.7 & 0.3 & 13.7 & - & - & 4.5 & 99.8 \\
\hline 0.2 & 0.2 & - & - & - & - & - & - & 21.0 & 0.2 & 8.4 & - & - & 5.8 & 100.0 \\
\hline 0.3 & 0.3 & - & 0.3 & - & - & - & - & 2.7 & - & 10.4 & - & - & 2.1 & 99.7 \\
\hline 3.8 & - & - & - & 1.3 & - & - & - & 3.8 & - & 7.7 & - & - & 1.3 & 100.1 \\
\hline 0.2 & 0.2 & - & - & - & - & - & - & 17.7 & 0.2 & 2.0 & 0.2 & - & 1.6 & 100.0 \\
\hline 1.0 & - & - & - & - & - & - & - & 1.0 & - & 8.2 & - & - & 41.5 & 99.9 \\
\hline 0.2 & 0.2 & - & - & - & 0.2 & 0.2 & - & 6.0 & 0.2 & 9.0 & - & - & 31.0 & 99.9 \\
\hline 0.9 & - & - & - & - & - & - & - & 64.0 & - & 8.2 & 0.3 & - & 13.2 & 99.8 \\
\hline 0.3 & - & - & 0.3 & - & - & - & - & 0.3 & - & 23.0 & - & - & 1.2 & 99.7 \\
\hline 0.3 & - & - & - & - & - & - & - & 1.4 & - & 22.2 & - & - & 0.9 & 100.0 \\
\hline- & 0.3 & - & 0.3 & - & - & - & - & 0.5 & - & 21.4 & - & - & 0.6 & 99.7 \\
\hline 0.4 & - & - & - & - & - & - & 0.2 & 5.0 & - & 3.8 & - & - & 0.9 & 100.0 \\
\hline 1.2 & 0.2 & - & - & - & - & - & - & 4.3 & - & 8.4 & - & - & 0.2 & 100.0 \\
\hline 0.2 & - & - & 0.2 & - & - & - & - & 0.2 & - & 8.0 & - & - & 57.1 & 100.0 \\
\hline - & - & - & - & - & - & - & - & - & - & 11.5 & - & - & 83.8 & 100.0 \\
\hline 1.4 & 0.2 & - & 0.2 & 0.2 & - & - & - & 0.4 & - & 9.1 & - & - & 0.2 & 99.8 \\
\hline 0.2 & - & - & - & - & - & - & - & 0.2 & - & 10.4 & - & - & 5.4 & 99.8 \\
\hline 0.3 & - & - & - & - & - & - & - & 0.3 & - & 0.6 & - & - & 92.4 & 99.8 \\
\hline 0.4 & - & - & 0.2 & - & - & - & - & 0.2 & - & 8.6 & - & - & 28.0 & 100.0 \\
\hline 1.1 & - & - & - & - & - & - & - & 0.5 & - & 9.0 & - & - & 3.5 & 100.3 \\
\hline 0.6 & 0.2 & - & - & - & - & - & - & 0.2 & - & 14.5 & - & - & 0.6 & 99.7 \\
\hline 0.2 & - & - & - & - & - & - & - & - & - & 0.5 & - & - & 70.8 & 99.9 \\
\hline - & - & - & 0.2 & - & - & - & - & - & 0.2 & 10.9 & 0.2 & - & 50.8 & 99.6 \\
\hline 0.3 & - & - & - & - & - & - & - & 0.3 & - & 19.5 & - & - & 2.2 & 99.7 \\
\hline 0.1 & - & - & - & - & - & - & - & 4.6 & - & 16.0 & - & 0.1 & 27.4 & 100.0 \\
\hline- & - & - & - & - & - & - & - & 1.7 & - & 11.0 & - & - & 2.7 & 99.8 \\
\hline 0.5 & - & - & 0.1 & - & - & - & - & 0.1 & 0.1 & 6.8 & - & 0.1 & 5.9 & 99.8 \\
\hline 0.2 & - & - & - & - & - & - & - & 0.2 & 0.2 & 1.1 & - & - & 66.0 & 99.8 \\
\hline 0.2 & - & - & - & - & - & - & - & - & - & 16.4 & - & - & 27.2 & 99.7 \\
\hline 0.6 & - & - & - & - & - & - & - & 26.9 & 0.6 & 6.8 & - & - & 2.2 & 100.2 \\
\hline- & - & - & - & - & - & - & - & 7.7 & - & 8.0 & - & 0.1 & 0.4 & 99.7 \\
\hline
\end{tabular}

8 to 11 - Units 4 and 5, Riss-Würm; Cores 12 to 24 - Unit 6, Riss; Cores 25 to 29 - Unit 7; Mindel-Riss; Cores 30 to 49 - Unit 8, Mindel; Cores 50 to 68 - Unit 9, Gunz-Mindel/Cromer.

carbonates are present in considerable amounts and, in the upper part of Unit 4, many garnets were observed. Apatite and sphene constantly occur, whereas zircon is present sporadically.

The main part of the light subfraction is often represented by weathered rock fragments (up to $51.6 \%$ ) or quartz (up to $47.3 \%$ ). Feldspars are always present in much lesser abundances than is quartz. Multicolored micas and carbonates are always present in considerable quantities; diatoms and glauconite are encountered sporadically. The predominance of quartz over feldspars indicates the considerable importance of a Caucasian terrigenous source. But the weathered rock fragments, occurring in such large abundance, suggest a genetic connection with the southern drainage area. Thus, terrigenous matter in Units 4 and 5 is of mixed origin, with alternation between a southern and northeastern source. 
TABLE 1B

Mineral Composition of Light (sp. w. <2.9) Subfraction 0.1-0.05 mm in the Bottom Sediments of Hole 379A (Leg 42B)

\begin{tabular}{|c|c|c|c|c|c|c|c|c|c|c|c|c|c|c|c|c|c|}
\hline $\begin{array}{c}\text { Sample } \\
\text { (Interval in } \mathrm{cm} \text { ) }\end{array}$ & 1 & 2 & 3 & 4 & 5 & 6 & 7 & 8 & 9 & 10 & 11 & 12 & 13 & 14 & 15 & 16 & $\begin{array}{c}\text { Total (\%) } \\
\text { From Sub- } \\
\text { fraction }\end{array}$ \\
\hline $1-2,70-78$ & 4.1 & - & 15.0 & 18.3 & 2.3 & 15.9 & 12.1 & 0.3 & 1.4 & - & - & - & 22.2 & 8.2 & - & - & 99.8 \\
\hline $4-3,30-40$ & - & 1.1 & 2.6 & 22.4 & - & 8.0 & 40.1 & - & 0.3 & - & 0.9 & - & 14.8 & 9.8 & - & - & 100.0 \\
\hline $4-5,125$ & - & 0.5 & 4.3 & 26.0 & 0.5 & 9.5 & 52.0 & - & 0.7 & - & - & - & - & 6.2 & - & 0.5 & 100.2 \\
\hline $6-2,32-38$ & 0.2 & 0.2 & 7.7 & 28.0 & 0.6 & 8.0 & 47.4 & - & - & - & 0.2 & - & 0.2 & 7.3 & - & 0.2 & 100.0 \\
\hline $6-5,36-46$ & 0.2 & 1.0 & 2.9 & 26.0 & 0.2 & 10.8 & 46.5 & - & - & - & 0.2 & - & - & 11.7 & - & 0.5 & 100.0 \\
\hline $7-2,20-30$ & 0.2 & 0.5 & 5.3 & 13.5 & 0.8 & 2.8 & 22.6 & - & - & - & 43.6 & - & - & 10.7 & - & 0.1 & 100.1 \\
\hline $8-4,14-16$ & 1.2 & 1.6 & 2.6 & 46.5 & 0.2 & 7.4 & 33.1 & 0.2 & 0.2 & - & 0.4 & - & 0.7 & 5.0 & - & 0.9 & 100.0 \\
\hline $9-3,100-108$ & 7.5 & 5.2 & - & 27.0 & - & 14.0 & 40.1 & - & - & - & 0.3 & - & 2.2 & 3.9 & - & - & 100.2 \\
\hline $9-5,50-58$ & - & 2.2 & 0.9 & 28.8 & 0.2 & 8.2 & 51.6 & - & - & - & 0.2 & - & 2.0 & 5.7 & - & 0.2 & 100.0 \\
\hline $10-1,120-130$ & 0.3 & 0.3 & 2.8 & 29.5 & 0.3 & 13.5 & 43.6 & 0.3 & - & - & - & - & - & 9.1 & - & 0.3 & 100.0 \\
\hline $10-3,85-93$ & - & 0.9 & 2.5 & 28.8 & 2.5 & 11.2 & 40.0 & - & 0.3 & - & 0.3 & - & - & 6.6 & 6.3 & 0.6 & 100.0 \\
\hline $10-5,11-13$ & 4.2 & 2.1 & 0.9 & 47.3 & 0.3 & 12.0 & 25.0 & - & - & - & 0.3 & - & - & 7.6 & - & 0.3 & 100.0 \\
\hline $11-2,55-64$ & 2.3 & 0.6 & 6.2 & 22.9 & 1.0 & 28.5 & 34.6 & - & - & - & 0.3 & 0.3 & - & 3.3 & - & - & 100.0 \\
\hline $11-5,77-78$ & 0.3 & 0.9 & 3.5 & 28.0 & 0.6 & 8.7 & 42.3 & - & - & - & - & - & 0.6 & 14.8 & - & 0.3 & 100.0 \\
\hline $13-5,1-7$ & 0.7 & 0.3 & 1.6 & 49.5 & - & 7.7 & 30.9 & - & 0.3 & - & - & 0.3 & 0.7 & 7.0 & - & 0.7 & 99.7 \\
\hline $14-4,0-10$ & 0.5 & 0.2 & 0.2 & 45.0 & 0.2 & 7.6 & 36.2 & - & - & 0.2 & - & - & - & 9.0 & - & 0.9 & 100.0 \\
\hline $15-2,55-65$ & 0.2 & 0.8 & 4.8 & 27.6 & 0.2 & 12.8 & 45.2 & - & - & - & - & 0.2 & - & 8.0 & - & 0.2 & 100.0 \\
\hline $15-5,2-12$ & 0.3 & 0.7 & 3.2 & 34.2 & 0.3 & 13.8 & 36.7 & 0.7 & 0.3 & - & - & - & 0.3 & 9.2 & - & 0.3 & 100.0 \\
\hline $16-2,50-52$ & 0.2 & 0.5 & 0.7 & 65.1 & 0.2 & 12.3 & 14.8 & - & - & - & 0.2 & 0.2 & - & 3.6 & - & 2.2 & 100.0 \\
\hline $16-3,17-27$ & - & - & 0.6 & 71.5 & - & 12.0 & 11.9 & - & - & - & - & - & - & 3.4 & - & 0.6 & 100.0 \\
\hline $17-1,25-35$ & - & 0.6 & 1.1 & 28.0 & 0.3 & 9.2 & 53.2 & - & - & - & 0.3 & - & 0.3 & 6.7 & - & 0.3 & 100.0 \\
\hline $19-3,84-85$ & 12.0 & 4.8 & 10.6 & 26.1 & 0.2 & 10.9 & 24.1 & 0.8 & 0.2 & 0.2 & 0.2 & - & 0.2 & 9.5 & - & 0.2 & 100.0 \\
\hline $19-6,132-134$ & 0.5 & 3.2 & 6.6 & 28.9 & 0.2 & 14.2 & 34.4 & - & 0.2 & 0.2 & 0.2 & 0.5 & 0.7 & 10.0 & - & 0.2 & 100.0 \\
\hline $20-3,23-25$ & 0.2 & 0.2 & 1.0 & 25.0 & 0.8 & 11.2 & 54.2 & - & 0.2 & 0.2 & - & - & - & 7.0 & - & - & 100.0 \\
\hline $21-6,0-10$ & 0.2 & 4.6 & 6.2 & 30.0 & 0.6 & 6.9 & 34.0 & - & - & - & 0.2 & 0.8 & 0.2 & 16.3 & - & - & 100.0 \\
\hline $23-2,0-11$ & 2.0 & 0.3 & 1.3 & 6.5 & 3.3 & 2.0 & 77.5 & - & 1.6 & 0.3 & 0.3 & 0.9 & 1.6 & 1.6 & 0.3 & 0.3 & 99.8 \\
\hline $23-2,150-158$ & 0.2 & 0.5 & 3.0 & 28.2 & 0.5 & 8.3 & 50.1 & - & 0.2 & 0.2 & - & - & - & 8.8 & - & - & 100.0 \\
\hline $25-3,120-121$ & - & 6.1 & 1.4 & 23.6 & 5.0 & 17.9 & 37.1 & - & - & 5.0 & 1.1 & 0.3 & 1.1 & 1.4 & - & - & 100.0 \\
\hline $25-3,124-125$ & 0.2 & 0.4 & 1.9 & 28.3 & 0.4 & 11.1 & 50.0 & 0.4 & 0.2 & - & 0.2 & - & - & 7.1 & - & - & 100.2 \\
\hline $25-3,128-129$ & 0.2 & 4.6 & 3.4 & 15.3 & 0.2 & 12.7 & 54.5 & - & 0.2 & - & 0.2 & - & - & 8.7 & - & - & 100.0 \\
\hline $26-2,27-29$ & 0.7 & 0.7 & 7.2 & 35.3 & 0.2 & 11.7 & 23.6 & - & 0.2 & 0.7 & - & 0.5 & - & 19.0 & - & 0.2 & 100.0 \\
\hline $27-5,58-60$ & 0.2 & 3.6 & 9.5 & 31.0 & 0.2 & 11.9 & 25.4 & - & 0.2 & - & - & - & 0.2 & 17.8 & - & - & 100.0 \\
\hline $28-2,24-26$ & 4.9 & 0.2 & 6.6 & 32.0 & - & 12.0 & 24.9 & - & 0.5 & 0.5 & - & 0.2 & - & 17.5 & - & 0.7 & 100.0 \\
\hline $28-6,74-76$ & 0.2 & 0.2 & 4.7 & 32.0 & - & 27.0 & 25.8 & 0.2 & 0.2 & 0.2 & - & 0.2 & - & 9.3 & - & - & 100.0 \\
\hline $28-6,78-80$ & 5.4 & 3.2 & 4.4 & 32.0 & 0.3 & 15.9 & 27.0 & - & - & - & - & - & - & 11.8 & - & - & 100.0 \\
\hline $29-1,94-96$ & 7.5 & 3.5 & 6.0 & 29.6 & - & 9.5 & 24.5 & - & 0.2 & 0.4 & - & 1.1 & - & 17.5 & - & 0.2 & 100.0 \\
\hline $29-5,98-105$ & 1.4 & 1.1 & 2.1 & 30.2 & 0.3 & 5.2 & 8.4 & - & - & - & - & 1.7 & 3.5 & 46.1 & - & - & 100.0 \\
\hline $37-1,84-86$ & 0.3 & 4.0 & 6.0 & 34.0 & - & 10.5 & 27.6 & - & 0.3 & - & - & - & - & 17.0 & 0.3 & - & 100.0 \\
\hline $40-2,133-135$ & 5.9 & 6.1 & 6.3 & 25.2 & 0.5 & 8.4 & 32.0 & - & 0.2 & 0.2 & - & - & 0.2 & 15.0 & - & - & 100.0 \\
\hline $42-3,20-22$ & 6.0 & 6.2 & 6.4 & 26.2 & 0.5 & 8.6 & 30.1 & - & 0.2 & 0.4 & - & - & 0.4 & 15.2 & - & - & 100.2 \\
\hline $42-3,25-27$ & 0.2 & 1.3 & 4.1 & 40.0 & 0.5 & 9.3 & 30.0 & - & 0.2 & - & - & - & - & 14.2 & - & 0.2 & 100.0 \\
\hline $46-2,104-106$ & 0.5 & 0.7 & 2.8 & 42.0 & 0.2 & 14,3 & 22.6 & - & 0.2 & 0.2 & - & - & - & 16.5 & - & - & 100.0 \\
\hline $47-6,106-108$ & 2.9 & 0.7 & 3.3 & 36.8 & 0.4 & 9.5 & 28.2 & - & 0.2 & - & - & 0.4 & - & 17.6 & - & - & 100.0 \\
\hline $50-3,144-146$ & 1.1 & 0.2 & 4.6 & 20.3 & - & 5.6 & 57.6 & - & 0.2 & - & - & 0.2 & - & 10.2 & - & - & 100.0 \\
\hline $50-5,12-21$ & 1.7 & 1.9 & 3.0 & 16.3 & - & 2.9 & 70.4 & - & 0.2 & - & - & - & 0.2 & 3.3 & - & - & 99.9 \\
\hline $51-2,20-22$ & 10.5 & 6.4 & 8.3 & 25.4 & - & 9.0 & 28.5 & - & 0.5 & 1.4 & - & - & 0.2 & 9.6 & - & 0.2 & 100.0 \\
\hline $52-1,55-65$ & 0.2 & 2.7 & 5.7 & 26.4 & 0.5 & 7.9 & 36.1 & - & 0.5 & - & - & - & 0.2 & 16.0 & - & 0.5 & 96.7 \\
\hline $54-2,20-34$ & 0.3 & 0.3 & 0.6 & 2.4 & - & 0.7 & - & - & 0.3 & - & - & - & 0.3 & 95.1 & - & - & 100.0 \\
\hline $56-1,18-20$ & 0.5 & 0.2 & 4.7 & 38.0 & 0.2 & 10.6 & 34.8 & 0.2 & 0.5 & 0.2 & - & - & - & 10.1 & - & - & 100.0 \\
\hline $58-4,143-145$ & 0.8 & 4.3 & 4.8 & 32.6 & 0.2 & 11.4 & 36.6 & - & 0.2 & - & - & - & - & 9.1 & - & - & 100.0 \\
\hline $58-4,145-147$ & 0.2 & 2.5 & 6.9 & 30.0 & 0.2 & 12.9 & 34.8 & - & 0.4 & 0.4 & - & - & - & 11.7 & - & - & 100.0 \\
\hline $67-4,110-120$ & - & 1.1 & 2.7 & 16.0 & 1.1 & 16.8 & 54.3 & - & 0.2 & - & - & - & - & 7.8 & - & - & 100.0 \\
\hline $68-5,84-86$ & 0.3 & 3.8 & 6.5 & 28.0 & - & 8.8 & 42.3 & - & 0.3 & 0.3 & - & - & - & 9.4 & - & 0.3 & 100.0 \\
\hline
\end{tabular}

Note: 1 , colorless mica; 2 , yellow mica; 3 , green mica; 4 , quartz; 5 , feldspars $(>1.545) ; 6$, feldspars $(<1.545) ; 7$, weathered rock grains, 8 , colorless glass (volcanic); 9 , foraminifers; 10 , biogenic carbonates; 11, diatoms; 12 , spicules; 13 , plant debris; 14 , carbonates; 15 , zeolites; 16 , flauconite.

The mineral composition of Unit 6 (Riss) is not uniform. Its upper part (Cores 13 to 15 ) corresponds to the coldest stage of sedimentation and consists of terrigenous sandy silts as well as silty muds and clays. The assemblage of heavy minerals is similar to that of Units 4 and 5, except that there are smaller amounts of sulfides, and more black opaque minerals.

The main part of the heavy subfraction consists of epidotes, clinopyroxenes, and hornblendes with, as a rule, epidotes or pyroxenes predominating. Lower, in the fine-grained sand $(16-2,50-52 \mathrm{~cm})$ and fine silt $(16-$ $3,17-27 \mathrm{~cm}$ ) interbeds, the clinopyroxene contents are sharply decreased $(4.6 \%$ to $5.3 \%)$ and the contents of zircon $(7.6 \%$ to $11.2 \%)$, garnet $(5.5 \%$ to $13.1 \%)$, and staurolite $(1.2 \%$ to $1.6 \%)$ increased. This assemblage of heavy minerals is characteristic of the Don River loads.

The light subfraction is dominated either by quartz or weathered rock fragments. Feldspars, micas, 
carbonates, though sometimes in notable abundance, are of minor importance. The mineral assemblage in the unit's upper part indicates a major role of the southern and Caucasian drainage areas.

The middle portion of Unit 6 (Cores 17 to 21), deposited during a warmer but variable climate, also consists of terrigenous sediments (sands, coarse and fine silts, silty muds, and clays). The basic part of the heavy subfraction is represented here by clastic minerals; only in one sample of fine silty mud (19-3, 84$85 \mathrm{~cm})$ is it mainly sulfides $(87.7 \%)$. The heavy assemblage is variable and in contrast to the upper part of Unit 6, is characterized by sharply decreased contents of clinopyroxenes. In some samples, garnet, spinel, and apatite contents are relatively greater; micas (chlorite, muscovite) are locally abundant (up to $20.3 \%$ to $39.8 \%$ ).

In some interbeds $(20-3,23-25 \mathrm{~cm})$ heavy minerals are chiefly represented by hornblende, epidote-zoisite, clinopyroxenes, micas, and black opaque minerals. In other interbeds they mainly consist of epidotes, micas and hornblendes; the third type of interbed contains hornblende, epidote, clinopyroxenes, and abundant opaques. These alternations suggest sudden and repeated changes of source areas. The Kuban loads are recognized by high contents of hornblende in combination with epidotes, micas, and garnets (17-1, $25-35 \mathrm{~cm}$ ). Other Caucasus and probably Crimea rivers deliver material enriched in epidote, hornblende, and micas (chlorite, muscovite). Less frequently the southern sources were of considerable importance, as witnessed by increased contents of clinopyroxenes (20$3,23-25 \mathrm{~cm} ; 23-2,150-158 \mathrm{~cm}$ ).

The light subfraction is mainly represented either by quartz or by weathered rock fragments. Feldspars and micas are present in significant quantities, and the feldspars are always less abundant than quartz, especially in the unit's upper part.

The lower portion of the unit (Cores 22 to 24), deposited during the Riss initial cold period, is characterized by mineral assemblages similar to that of the unit's upper part.

Mindel-Riss deposits (Unit 7) contain low-calcareous muds and fine silty muds with terrigenous coarse silt interbeds. Turbidites are also present. In the upper portion (Core 25) fine silty mud in part of some turbidite layers was studied in detail. At its base (25-3, $128-129 \mathrm{~cm}$ ), clinopyroxenes are predominant, making up $64 \%$. The epidote content amounts to $10.1 \%$. Amphiboles occur in a very small amount $(0.6 \%)$. Upwards through the layer the concentration of clinopyroxenes is sharply decreased. The content of the epidote-zoisite group increases in the same direction. There is abundant hornblende in the layer's middle part $(14.6 \%)$, and chlorite is present throughout the interbed.

In another turbidite $(28-6,74-80 \mathrm{~cm})$ consisting of coarse and fine silt, the heavy minerals are mainly represented by epidote-zoisite (51\% to $56.5 \%)$, hornblende ( $13.8 \%$ to $16.0 \%)$, clinopyroxenes $(4.3 \%$ to $5.0 \%$ ), and micas, i-e., by the epidote-amphibolepyroxene-mica assemblage.
Fine silty mud interbeds contain multicolored micas, found in combination with significant amounts of epidotes, amphiboles, and clinopyroxenes. In a single interbed of pelitic mud (clay), 29-1, $94-96 \mathrm{~cm}$, more than half of the heavy minerals consists of iron sulfides, epidote, and chlorite. Among the light minerals, quartz is usually predominant, followed by weathered lithoclasts, feldspars, micas, and carbonates. Weathered grains, making up $54.5 \%$, prevail in the turbidite interbed $25-3,128-129 \mathrm{~cm}$.

Thus, in Unit 7 an alternation of heavy mineral assemblages occurs, involving: (1) an epidotehornblende-mica-pyroxene assemblage; (2) a micacarbonate-epidote-hornblende assemblage; (3) a pyroxene-epidote assemblage; and (4) an assemblage of epidote alone.

The first and the second assemblages are encountered most frequently. High epidote contents, between $51.0 \%$ and $56.5 \%$, are characteristic of the first assemblage. Such values are not found in Recent deep-sea sediments. It may be that the high epidote values are partly the result of mineralogical differentiation by suspension currents. As was mentioned above, the considerable enrichment in epidotes is observed in the upper part of the turbidite interbed in Core 25. All the assemblages enumerated are most likely linked genetically to metamorphic series of the Great Caucasus (to some extent the Crimea) and to a lesser degree with the southern drainage area.

Mindel deposits (Unit 8) are mainly represented by terrigenous muds poor in organic matter. The epidotemica-hornblende assemblage and mica-epidote assemblage occur in fine silty muds; either micas or epidotes dominate, and black opaque minerals and hydrogoethite are present in significant quantities. The heavy mineral composition indicates that the material is mainly supplied from the Caucasus.

In silty-clayey mud $(42-3,20-22 \mathrm{~cm})$ the most prevalent heavy minerals consist of sulfides (92.4\%), hornblendes, and epidotes. In the light subfraction, quartz and weathered lithoclasts occur almost in equal amounts, followed by carbonates, feldspars, and micas. The quartz is more abundant sometimes than feldspars.

In most samples of Günz-Mindel sediments (Unit 9) the epidote-mica-amphibole mineral assemblage is recognized with epidotes predominant, reaching $38.0 \%$ to $64.8 \%$ in some interbeds; multicolored micas follow. Only in some interbeds are clinopyroxenes found in notable abundances $(52-1,55-65 \mathrm{~cm} ; 67-4,110-120 \mathrm{~cm}$; $68-5,84-86 \mathrm{~cm})$. Opaque clastic minerals, more often hydrogoethite, play a significant role in a number of interbeds. Of the light minerals, quartz and weathered grains are present in the greatest amounts; they dominate alternately; feldspars, micas, and carbonates follow. Only in a single instance (54-2, 20-34 cm) does the light subfraction consist almost entirely of carbonates.

On the basis of the heavy mineral composition, the main source provinces at that time of the deposition of Unit 9 were the great Caucasus; during some periods the southern drainage area was of significant importance. 
TABLE 2

Mineral Composition of Heavy (sp.w. $>2.9$ ) Subfraction 0.1-0.05 mm, Hole 380, Leg 42B

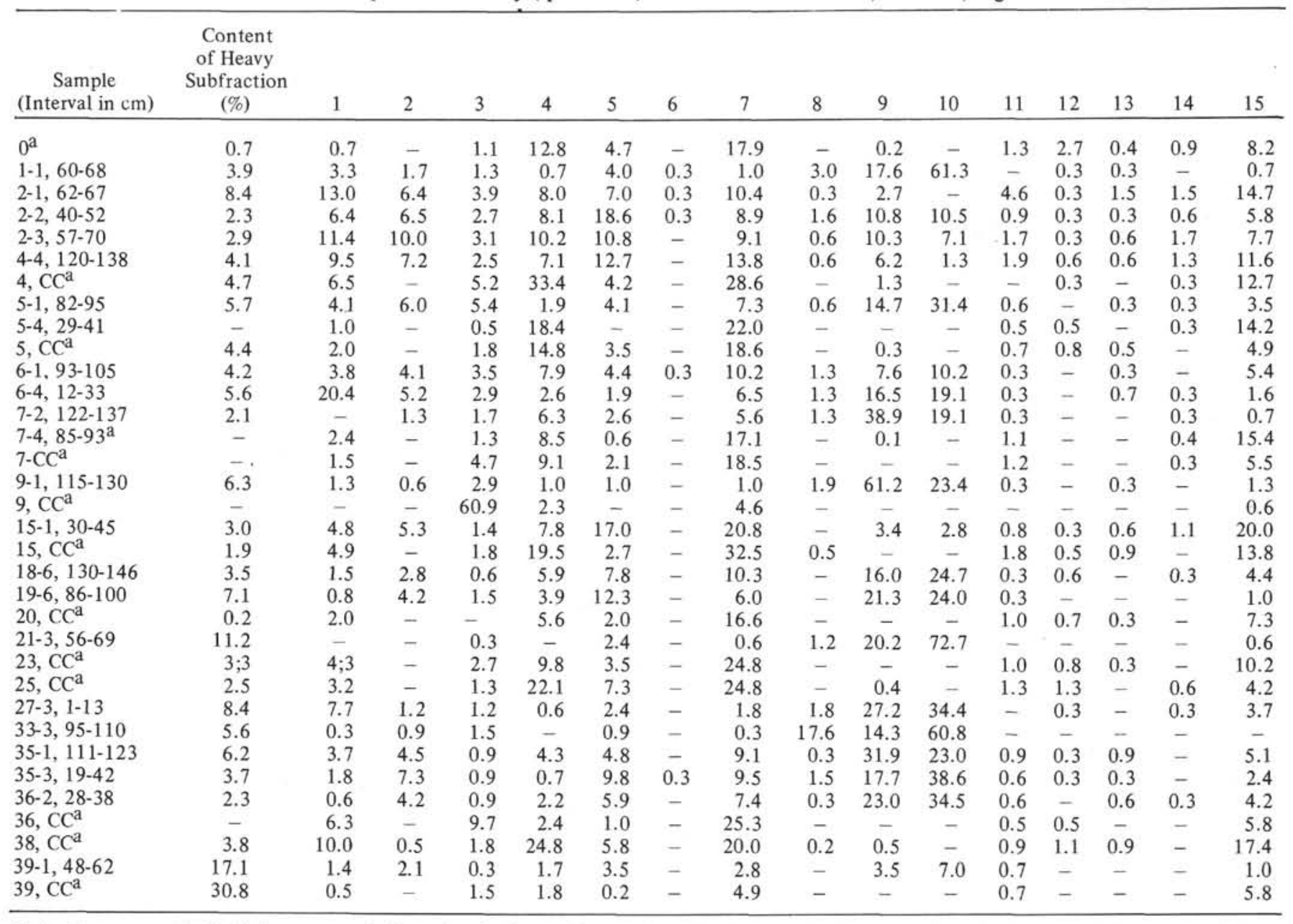

Note: 1, opaque black; 2 , leucoxene; 3 , limonite, hydrogoethite; 4 , hornblende; 5 , actinolite-tremolite; 6 , alkalic amphiboles; 7 , epidotezoisite; 8 , biotite; 9 , chlorite; 10 , muscovite; 11 , zircon; 12 , apatite; 13 , sphene; 14 , rutile; 15 , garnet; 16 , tourmaline; 17 , staurolite; 18 , chloritoid; 19, disthene (kyanite); 20, sillimanite; 21 , andalusite; 22 , rare (brukite, vollastonite etc.); 23, clinopyroxene; 24 , orthopyroxene;

\section{Holes 380/380A}

This site is located in the Recent sediments Bosphorus mineralogical province (Figure 1), which is characterized by high contents of micas, garnet, and quartz (Trimonis, 1972). At Station 1558, situated near Site 380 , in the light and heavy subfractions of coarsesilty material, multicolored micas dominate $(>80 \%)$. In the heavy subfraction, hornblende, epidote-zoisite, opaques, etc., are found in small quantities. Garnet, zircon, tourmaline, and pyroxenes are encountered in single grains. Towards the Bosphorus (Stations 244, 247), the mica content decreases considerably, whereas the content of hornblende, epidote-zoisite, and garnets increases. In sediments opposite the Sakarya River (Station 248), epidote-zoisite is the most abundant mineral among all the heavy clastics and amphiboles are present in small amounts; tourmaline and garnet occur in notable quantities. In coarse-silt samples from the submarine Sakarya Valley floor, amphiboles and epidotes occurring in approximately equal amounts, are predominant over other heavy minerals, excluding opaques; clinopyroxenes, micas, garnets, leucoxene, and magnetite are also abundant.
Northwestward from the drilling area, where the Danube sediments enter (Stations 240, 1560), heavy clastic minerals are mainly represented by epidotezoisite, hornblende, garnet, and by relatively large quantities of tourmaline, and visible amounts of pyroxene are recorded at Station $1560(3.7 \%)$.

Northward from Site 380/380A (Station 236) clastic minerals are dominated by pyroxenes and epidotezoisite, but the amphibole contents are decreased and clastic opaque minerals (especially black ones and limonite) are common; zircon, tourmaline, and garnet are minor. Still further northward, the heavy mineral composition changes again; amphiboles, epidotezoisite, garnet, micas, and opaque minerals (black ones and limonite) become of primary importance. The Recent sediments of this area are supplied mainly by the Danube River.

Würm sediments at Site 380/380A (Unit B-1-c) contain terrigenous sandy silts and muds. As shown by Table 2, the heavy mineral composition is highly variable. In some interbeds it is represented by amphiboles (prevalent minerals), epidote-zoisite, and garnets; in other interbeds this assemblage is supplemented with micas, but in other interbeds micas 
TABLE 2 - Continued

\begin{tabular}{|c|c|c|c|c|c|c|c|c|c|c|c|c|c|c|c|}
\hline 16 & 17 & 18 & 19 & 20 & 21 & 22 & 23 & 24 & 25 & 26 & 27 & 28 & 29 & 30 & Total $(\%)$ \\
\hline 0.9 & 1.8 & - & - & - & - & - & 3.5 & 1.1 & - & 0.7 & 1.5 & - & 35.6 & 4.0 & 100.0 \\
\hline 0.3 & - & - & - & 0.7 & 0.3 & - & 1.3 & - & - & 2.3 & - & - & - & - & 100.4 \\
\hline 0.3 & - & 0.3 & - & - & 1.2 & 1.5 & 9.3 & 2.1 & - & 2.4 & - & 0.3 & 3.1 & 4.6 & 99.7 \\
\hline 0.6 & 0.3 & - & - & 0.6 & 0.3 & 0.6 & 2.8 & 1.8 & 2.5 & 3.7 & 0.3 & 0.3 & 1.2 & 3.2 & 100.5 \\
\hline 0.6 & - & 0.6 & 0.6 & 0.8 & 0.3 & 0.3 & 1.7 & 1.1 & 0.6 & 2.8 & - & 0.8 & 2.6 & 2.3 & 99.7 \\
\hline 0.9 & 0.3 & 0.6 & 0.3 & 0.9 & 0.9 & 0.3 & 3.2 & 0.9 & 0.6 & 2.3 & - & - & 8.8 & 3.9 & 100.8 \\
\hline 0.3 & 1.3 & - & 0.3 & - & - & - & 1.6 & 0.7 & - & - & 1.3 & - & 0.7 & 1.3 & 100.0 \\
\hline 0.3 & - & 0.3 & 0.3 & - & 0.3 & 0.6 & 2.2 & 0.3 & - & 0.6 & - & 0.6 & 12.8 & 0.9 & 99.4 \\
\hline 0.5 & 1.8 & - & 0.3 & - & - & - & 2.5 & 0.3 & - & - & 2.0 & - & 28.9 & 6.3 & 100.6 \\
\hline 0.3 & 0.7 & - & 0.3 & - & - & - & 0.7 & - & - & 1.2 & 1.8 & - & 43.2 & 3.9 & 100.0 \\
\hline 0.6 & - & - & 0.6 & - & 0.3 & 0.6 & 1.3 & - & 0.6 & 5.4 & - & - & 29.5 & 1.6 & 99.8 \\
\hline 0.3 & - & - & 1.0 & 0.3 & - & - & - & - & - & 4.9 & - & - & 13.3 & 1.3 & 100.4 \\
\hline- & - & 0.3 & 0.3 & - & 0.3 & 0.3 & 0.7 & - & - & 13.2 & - & - & 2.6 & 3.6 & 99.4 \\
\hline 0.2 & 0.9 & - & 0.6 & - & - & - & 1.7 & - & - & - & 2.4 & - & 47.2 & - & 99.9 \\
\hline- & - & - & - & - & - & - & - & - & - & - & 1.5 & - & 55.6 & - & 100.0 \\
\hline 0.3 & - & - & 0.3 & - & - & - & 1.0 & 0.3 & - & 1.6 & - & - & 0.3 & 0.3 & 100.3 \\
\hline- & - & - & - & - & - & - & - & - & - & - & - & - & 5.3 & 26.4 & 100.1 \\
\hline 1.4 & - & - & 0.6 & - & 0.6 & - & 0.3 & 1.4 & 1.7 & 3.1 & - & 0.3 & 3.4 & - & 98.9 \\
\hline 1.6 & 1.8 & - & 0.7 & 0.2 & - & - & 3.4 & 0.5 & - & 0.5 & 2.7 & - & 5.1 & 4.1 & 99.5 \\
\hline 0.9 & - & - & 0.3 & - & 0.3 & - & - & 0.3 & - & 17.0 & - & - & 4.4 & 0.3 & 98.7 \\
\hline 0.3 & - & - & 0.3 & - & - & 0.3 & - & - & - & 13.3 & - & - & 7.3 & 0.8 & 97.6 \\
\hline 0.7 & - & - & - & - & - & - & 1.6 & - & - & - & 1.6 & - & 60.6 & - & 100.0 \\
\hline 0.3 & - & - & 0.3 & - & 0.3 & - & - & - & - & - & - & 0.6 & 0.3 & - & 99.8 \\
\hline 0.5 & 1.3 & - & - & - & - & - & 1.7 & 0.5 & - & 1.0 & 1.5 & - & 31.6 & 4.5 & 100.0 \\
\hline 0.6 & 1.1 & - & 0.6 & - & - & - & 1.9 & 1.0 & - & 0.2 & 1.9 & - & 15.9 & 10.3 & 100.0 \\
\hline 0.6 & - & - & 0.3 & - & 0.3 & - & 0.3 & - & - & - & - & 1.8 & 9.6 & 4.9 & 100.4 \\
\hline- & - & - & - & - & - & - & - & - & - & - & - & 0.3 & 3.0 & - & 99.9 \\
\hline 0.6 & - & - & - & 0.3 & - & - & 0.3 & - & - & - & - & - & 9.4 & - & 100.3 \\
\hline 0.3 & - & - & 0.9 & 0.3 & - & 0.6 & - & - & - & - & - & 0.3 & 3.7 & - & 97.8 \\
\hline 0.6 & - & - & 0.3 & - & - & - & - & - & - & 0.3 & - & - & 12.0 & 1.9 & 99.8 \\
\hline- & 0.5 & - & - & - & - & - & 0.5 & 0.5 & - & - & 1.5 & - & 36.8 & 8.7 & 100.0 \\
\hline 0.9 & 3.2 & - & - & - & - & - & 1.4 & 1.2 & - & 0.2 & 1.2 & - & 1.8 & 5.6 & 99.4 \\
\hline - & - & - & - & - & - & - & 0.3 & - & - & - & - & - & 72.7 & 2.7 & 99.7 \\
\hline - & - & - & 0.2 & - & - & - & 0.7 & - & - & - & 0.3 & - & 83.4 & - & 100.0 \\
\hline
\end{tabular}

25 , volcanic glass, ash; 26 , carbonates; 27 , barite; 28 , glauconite; 29 , sulfides; 30 , rock fragments, etc. Cores 1 to 5 - Unit B-1-c, Würm, Cores 5-8 - Unit B-1-d, Riss-Würm; Cores 9 to 15 - Unit B-1-e, Riss; Cores 15 to 19 - Unit B-1-f; Mindel-Riss; Cores 19 to 35 - Units B-1-g,h, Mindel; Cores 36 to 40 - Unit B-2 Eopleistocene.

${ }^{\mathrm{a}}$ Data of V. P. Kazakova.

become the most abundant minerals; pyroxenes are of minor importance throughout the unit. Sillimanite, andalusite, sphene, zircon, apatite, and tourmaline are almost constantly present. Opaque minerals are represented by magnetite, black and red minerals, limonite, and leucoxene.

The bulk of the sediments is probably supplied by northwestern rivers, primarily the Danube. The alternating heavy mineral assemblages through the section may be linked with varying degrees of sediment differentiation during transport by currents. High mica contents in some interbeds suggests that at the time of their deposition the Danube mouth was more remote from the area studied, whereas in interbeds with increased contents of hornblendes, epidotes, garnets, it was closer. Sea level fluctuations may have been responsible for this changing relation.

The heavy clastic mineral assemblage of Riss-Würm deposits in Unit B-1-d essentially does not differ from those of previous units. The same threefold interbed alternation is present, the differences being in the distribution of accessory minerals. For instance, the content of opaque clastic, sphene, rutile, and metamorphic minerals is decreased, and where the assemblage consists mainly of amphiboles, epidotezoisite, and garnet, the epidotes are the most abundant. Their source was not only from the Danube, but from other metamorphic terraines such as that drained by the Dobrudga rivers. Possibly also during that time Paleozoic or older massifs, now submerged under water, were drained.

Riss deposits (Unit B-1-e), made up of silty muds and muds, are characterized by highly variable contents of heavy minerals (Table 2). In the upper part of Riss section micas (colorless and green) prevail, making up $86.5 \%$ of the total heavy subfraction. The lower part of the Riss deposit contains a garnet-epidote-amphibole assemblage of terrigenous minerals.

Mindel-Riss terrigenous muds are characterized by variable assemblages of terrigenous minerals. The heavy subfractions here contain high contents of micas $(18-6,130-146 \mathrm{~cm})$, and in another case $(15, \mathrm{CC})$ the same mineral assemblage (garnet-epidote-amphibole) as that of the early Riss is present. 
TABLE 3

Mineral Composition of Heavy (sp.w. >2.9) Subfraction 0.1-0.05 mm, Hole 380A, Leg 42B

\begin{tabular}{|c|c|c|c|c|c|c|c|c|c|c|c|c|c|c|c|c|}
\hline $\begin{array}{c}\text { Sample } \\
\text { (Interval in } \mathrm{cm} \text { ) }\end{array}$ & $\begin{array}{c}\text { Content } \\
\text { of Heavy } \\
\text { Subfraction } \\
(\%)\end{array}$ & 1 & 2 & 3 & 4 & 5 & 6 & 7 & 8 & 9 & 10 & 11 & 12 & 13 & 14 & 15 \\
\hline $5, \mathrm{CC}^{\mathrm{a}}$ & 4.7 & 6.4 & - & 2.2 & 5.3 & - & - & 11.3 & - & - & - & 0.8 & - & - & - & 10.8 \\
\hline $7, \mathrm{CC}^{\mathrm{a}}$ & 3.3 & 5.2 & - & 1.1 & 15.5 & 1.9 & - & 15.3 & - & - & - & 0.6 & - & 0.6 & - & 14.2 \\
\hline $8, \mathrm{CC}^{\mathrm{a}}$ & 2.3 & 7.9 & - & 3.0 & 3.0 & 0.5 & - & 14.8 & - & - & - & 1.8 & 1.0 & 0.3 & 0.8 & 16.8 \\
\hline $10, C^{a}$ & 2.4 & 1.2 & - & 3.6 & 19.9 & 5.4 & - & 21.5 & - & 1.8 & - & 1.2 & 1.6 & 0.2 & - & 8.2 \\
\hline $11-2,13-21$ & - & 0.6 & 5.1 & 6.7 & - & 0.3 & 1.0 & 0.3 & 2.2 & 20.7 & 5.7 & 2.6 & 0.6 & 1.6 & 0.6 & 4.1 \\
\hline $12, C^{\mathrm{a}}$ & 5.9 & 5.3 & - & 1.5 & 20.0 & 3.2 & - & 22.7 & - & 0.8 & - & 0.8 & 0.6 & 0.4 & 0.2 & 14.4 \\
\hline $14, \mathrm{CC}^{\mathrm{a}}$ & 12.8 & - & - & 10.4 & 1.1 & - & - & 5.7 & - & - & - & 0.6 & - & 0.6 & - & 1.1 \\
\hline $15-3,26-36$ & 3.0 & 2.3 & 2.9 & 0.3 & 6.0 & 2.0 & - & 4.9 & 1.2 & 54.4 & 11.5 & 0.3 & 0.3 & - & - & 2.6 \\
\hline $18, \mathrm{CC}^{\mathrm{a}}$ & 7.3 & 0.6 & - & 8.0 & 2.3 & - & - & 4.0 & - & - & - & 1.1 & - & - & - & 1.7 \\
\hline $19-2,0-16$ & 81.3 & 88.5 & - & 0.3 & - & - & - & 0.3 & - & 0.9 & - & - & - & - & - & - \\
\hline $20-2,39-51$ & 71.7 & 2.6 & - & 1.2 & - & 0.3 & - & 0.3 & 0.3 & 0.9 & 1.8 & - & - & - & - & 0.3 \\
\hline $20, C^{\mathrm{a}}$ & - & 1.3 & - & 2.5 & 1.4 & - & - & 3.2 & - & 0.3 & - & - & - & - & - & 2.2 \\
\hline $22, \mathrm{CC}^{\mathrm{a}}$ & - & - & - & 5.8 & 1.0 & - & - & 1.8 & - & - & - & - & - & - & - & 1.3 \\
\hline $23-5,77-87$ & 95.7 & - & - & - & - & 0.3 & - & - & - & - & 0.3 & - & - & - & - & - \\
\hline $25-2,45-61$ & 13.7 & 10.8 & 0.6 & 1.2 & 0.6 & - & - & 0.6 & 2.1 & 4.5 & 3.6 & - & - & - & 0.3 & 0.9 \\
\hline $25-2,123-126$ & 5.8 & 8.7 & 3.9 & 1.4 & 1.1 & 1.4 & - & 8.4 & 1.7 & 24.7 & 5.1 & 0.3 & - & 0.6 & - & 2.8 \\
\hline $26, \mathrm{CC}^{\mathrm{a}}$ & - & 4.3 & 0.5 & 3.3 & 16.6 & 0.8 & - & 20.3 & - & 0.5 & - & 2.3 & 1.0 & 1.0 & 0.8 & 15.1 \\
\hline $29, \mathrm{CC}^{\mathrm{a}}$ & - & - & - & - & 3.1 & 1.1 & - & 1.3 & - & - & - & - & - & - & - & 0.7 \\
\hline $30-1,108-120$ & 81.4 & - & - & - & 0.3 & 0.3 & - & 0.6 & - & 0.3 & 0.3 & - & - & - & - & - \\
\hline $30-2,38-50$ & 83.0 & 0.3 & 0.3 & 0.6 & - & - & - & - & - & 0.3 & 0.3 & - & - & - & - & - \\
\hline $33, \mathrm{CC}^{\mathrm{a}}$ & - & - & - & 9.3 & 1.0 & 0.8 & - & 5.1 & - & 0.2 & - & - & - & - & - & 1.2 \\
\hline $36, \mathrm{CC}^{\mathrm{a}}$ & - & 3.0 & - & 1.4 & 6.9 & 2.2 & - & 18.3 & - & - & - & 1.0 & 0.6 & - & 1.0 & 9.7 \\
\hline $41-4,10-20$ & 6.0 & 40.1 & 0.6 & 4.2 & 1.2 & - & - & 1.2 & 0.6 & 0.6 & 1.2 & - & 0.6 & - & - & - \\
\hline $43-1,0-13$ & 1.3 & 24.2 & 5.0 & 0.6 & - & 0.6 & - & 1.2 & - & 0.6 & 0.6 & - & - & - & - & - \\
\hline $43-3,112-126$ & 1.1 & 3.5 & 8.9 & 0.6 & - & - & - & 13.1 & 1.3 & 5.0 & 9.2 & 0.3 & 0.6 & 1.0 & 0.3 & 2.3 \\
\hline $43, \mathrm{CC}^{\mathrm{a}}$ & - & 0.8 & - & 3.5 & 4.0 & 0.8 & 0.3 & 22.6 & - & - & - & 0.3 & - & - & - & 0.3 \\
\hline $44-5,130-140$ & 1.8 & 5.3 & 0.3 & 3.6 & 0.3 & 0.6 & - & 0.3 & 1.0 & - & 1.6 & - & - & - & - & - \\
\hline $46-3,1-10$ & 1.8 & 3.0 & 2.3 & 17.5 & - & 0.3 & 0.7 & 16.0 & 0.3 & 1.7 & 1.0 & - & - & 1.0 & - & 1.3 \\
\hline $48, \mathrm{CC}^{\mathrm{a}}$ & - & 1.8 & - & 1.5 & 0.8 & - & - & 8.5 & - & 0.2 & - & 0.2 & - & 0.2 & - & 0.8 \\
\hline $51-4,34-50$ & 1.9 & 4.0 & 5.3 & 4.3 & - & - & - & 34.0 & 2.0 & 1.7 & 0.3 & 0.7 & 0.7 & 3.0 & 2.0 & 4.3 \\
\hline $52-2,0-12$ & 1.1 & 8.0 & 4.1 & 58.2 & 0.3 & - & - & 7.4 & - & 0.9 & 1.2 & - & - & 0.9 & 0.8 & 3.2 \\
\hline $53-2,1-15$ & 6.3 & 0.6 & 2.2 & 1.9 & - & 0.3 & - & 3.9 & - & - & 0.6 & 0.9 & - & - & - & 3.2 \\
\hline $56-1,95-105$ & 1.0 & 76.1 & 3.0 & 3.0 & - & - & - & 2.0 & 0.3 & 0.3 & - & 0.7 & 1.0 & 1.7 & 1.0 & 2.3 \\
\hline $56, \mathrm{CC}^{\mathrm{a}}$ & - & 1.1 & - & 6.5 & 0.5 & - & - & 3.0 & - & - & - & 0.5 & - & - & - & 1.9 \\
\hline $62-2,0-5$ & 0.2 & 39.2 & 4.1 & 7.5 & - & - & - & 3.8 & 1.3 & 5.0 & 1.6 & 2.2 & 3.1 & 2.8 & 1.3 & 3.5 \\
\hline $71, \mathrm{CC}^{\mathrm{a}}$ & - & 17.3 & - & 14.3 & 3.8 & 0.7 & - & 17.3 & - & - & - & 3.8 & - & - & - & 15.1 \\
\hline $75, \mathrm{CC}^{\mathrm{a}}$ & - & - & - & 4.9 & - & - & - & 6.4 & - & - & - & - & - & - & - & 4.9 \\
\hline $80, \mathrm{CC}^{\mathrm{a}}$ & - & 0.3 & - & 2.1 & 0.8 & - & 0.3 & 1.8 & - & - & - & 1.6 & - & 0.3 & 0.5 & 5.5 \\
\hline
\end{tabular}

Note: 1 , opaque black; 2 , leucoxene; 3 , limonite, hydrogoethite; 4 , hornblende; 5 , actinolite-tremolite; 6 , alkalic amphiboles; 7 , epidotezoisite; 8 , biotite; 9 , chlorite; 10 , muscovite; 11 , zircon; 12 , apatite; 13 , sphene; 14 , rutile; 15 , garnet; 16 , tourmaline; 17 , staurolite; 18 , chloritoid; 19 , disthene (kyanite); 20 , sillimanite; 21 , andalusite; 22 , rare (brukite, vollastonite, etc.) 23 , clinopyroxene; 24 , orthopyroxene; 25 , volcanic glass, ash; 26 , carbonates; 27 , barite; 28 , glauconite; 29 , sulfides; 30 , rock fragments, etc.; Cores 1 to 34 - Units

Mindel deposits (Units B-1-g, h) represented by terrigenous muds, often with sand-silty interbeds (turbidites), are mostly characterized by abundant micas. In some interbeds, the micas are absent and considerable parts of the heavy subfractions comprises epidote and amphiboles, and abundant sulfides. The garnet content in Mindel sections is not more than $10.2 \%$. On the whole, new terrigenous mineral assemblages are not apparent, and repeated alternation of the same heavy clastic mineral assemblages as in overlying units is observed.

The upper part of the early Pleistocene section (Unit B-2) consists almost entirely of clays and muds with some interbeds of sandy silts occurring. Sample 36-2, $28-38 \mathrm{~cm}$, carries a predominance of multicolored micas (57.8\%) with lesser amounts of amphiboles, epidotes, and garnets. In Sample 39-1, 48-62 cm, where the basic part of heavy subfraction is represented by iron sulfides $(72.7 \%)$, micas also predominate. In the interval between these layers, the amphibole-epidotegarnet mineral assemblage is present with some interbeds high in amphiboles where in others, epidotes are; in the latter case the garnet content is decreased. These interbeds are characterized by increased contents of iron hydroxides and black opaque minerals. Accessory clastic minerals in Unit B-2 always contain pyroxenes, tourmaline, and zircon in single grains.

In the upper part of Unit B-3 clay varves are widespread whereas in the remainder of the unit clay and carbonate (also diatomaceous) varves alternate. Sandy silt interbeds (turbidites) are observed throughout the sequence. Repeated alternation of three characteristic assemblages of heavy clastic minerals is present. They comprise (1) an amphibole-epidotegarnet assemblage, (2) mica with considerable contents of amphiboles, epidotes, and garnets and, (3) mica with small admixture of the other minerals (Table 3); the micas are mainly green. In a number of samples, the 
TABLE 3 - Continued

\begin{tabular}{|c|c|c|c|c|c|c|c|c|c|c|c|c|c|c|c|}
\hline 16 & 17 & 18 & 19 & 20 & 21 & 22 & 23 & 24 & 25 & 26 & 27 & 28 & 29 & 30 & Total, $\%$ \\
\hline- & 0.4 & - & - & - & - & - & 1.5 & - & - & - & - & - & 61.3 & - & 100.0 \\
\hline - & 1.1 & - & 0.2 & - & - & - & 0.9 & 0.2 & - & - & 0.9 & - & 37.4 & 4.9 & 100.0 \\
\hline 0.3 & 1.5 & - & 0.3 & - & - & - & 1.8 & 0.3 & - & - & 1.3 & - & 36.2 & 8.6 & 100.2 \\
\hline 0.6 & 0.8 & - & 0.4 & - & - & - & 1.0 & 0.4 & - & 0.6 & 1.4 & - & 18.3 & 11.9 & 100.0 \\
\hline 0.3 & - & 0.3 & 0.6 & 1.3 & 2.6 & - & 0.3 & - & - & - & - & - & 34.4 & 7.0 & 98.9 \\
\hline 0.4 & 0.8 & - & 0.4 & - & 0.2 & - & 1.5 & 0.6 & - & 0.2 & 1.1 & - & 17.1 & 7.7 & 99.9 \\
\hline- & - & - & - & - & - & - & 0.6 & - & - & - & 1.1 & - & 78.8 & - & 100.0 \\
\hline 0.6 & - & - & - & - & 0.3 & 0.5 & 0.3 & - & - & 2.9 & - & - & 2.3 & 4.6 & 100.2 \\
\hline- & - & - & - & - & - & - & 0.6 & - & - & - & - & - & 58.0 & 22.7 & 99.0 \\
\hline- & - & - & - & - & - & - & - & - & - & 0.3 & - & - & 9.7 & 0.3 & 100.3 \\
\hline - & - & - & - & - & - & - & 0.3 & - & - & 15.6 & - & - & 76.7 & 0.3 & 100.6 \\
\hline- & 0.3 & - & - & - & - & - & - & - & - & - & 0.3 & - & 88.1 & - & 99.6 \\
\hline - & 0.3 & - & 0.5 & - & - & - & 0.5 & - & - & - & 0.3 & - & 88.0 & - & 99.5 \\
\hline- & - & - & - & - & - & - & 0.3 & - & - & 0.9 & - & - & 98.2 & - & 100.0 \\
\hline- & - & - & - & - & 0.3 & - & - & - & - & 0.3 & - & - & 75.4 & 0.3 & 101.5 \\
\hline 0.8 & - & - & 0.6 & - & - & - & - & - & - & 3.7 & - & - & 29.2 & 5.1 & 99.5 \\
\hline 1.0 & 1.0 & - & 0.3 & - & - & - & 1.8 & 0.8 & - & - & 2.3 & - & 19.6 & 6.8 & 100.1 \\
\hline- & - & - & 0.2 & - & - & - & 1.3 & 0.7 & - & - & 0.4 & - & 91.3 & - & 100.1 \\
\hline- & - & - & - & - & - & - & - & - & - & - & - & - & 96.6 & 1.7 & 100.1 \\
\hline - & - & - & - & - & - & - & - & - & - & - & - & - & 98.2 & - & 100.0 \\
\hline- & 0.4 & - & 0.2 & - & - & - & 0.4 & - & - & - & 0.4 & - & 81.0 & - & 100.0 \\
\hline 0.4 & 0.4 & - & - & - & - & - & 2.0 & - & - & 0.8 & 0.6 & - & 46.2 & 5.5 & 100.0 . \\
\hline- & - & - & - & - & - & - & - & - & - & 1.2 & - & - & 47.9 & 1.2 & 100.6 \\
\hline- & - & - & - & - & - & - & - & - & - & 1.9 & - & - & 41.0 & 19.9 & 95.6 \\
\hline 0.6 & - & - & - & - & - & - & 0.3 & 0.3 & - & - & - & - & 29.3 & 23.2 & 99.8 \\
\hline- & 0.8 & - & - & - & - & - & 1.8 & - & - & - & 1.0 & - & 61.0 & 4.3 & 101.5 \\
\hline- & - & - & - & - & - & - & - & - & 1.0 & - & - & - & 72.8 & 13.9 & 100.7 \\
\hline 0.3 & - & - & - & - & 0.7 & - & - & - & - & 9.3 & - & - & 37.0 & 1.6 & 94.0 \\
\hline 0.5 & - & - & 0.5 & - & - & - & 0.8 & - & - & - & 0.2 & - & 83.8 & - & 99.8 \\
\hline 1.0 & - & - & 0.7 & 0.7 & 2.7 & 2.0 & 0.7 & 0.3 & 0.3 & - & - & - & 19.3 & 10.6 & 100.6 \\
\hline- & - & - & 0.3 & - & 3.0 & 0.9 & - & - & - & 0.3 & - & - & 13.3 & - & 102.8 \\
\hline- & - & - & - & - & - & 1.3 & 0.3 & 0.3 & - & 0.3 & - & 0.6 & 80.8 & 1.9 & 99.1 \\
\hline- & - & - & 0.3 & 0.3 & - & - & - & - & - & 0.7 & 0.3 & - & 5.7 & 0.7 & 99.4 \\
\hline - & - & - & - & - & - & - & 0.5 & - & - & - & 6.7 & - & 76.9 & 2.4 & 100.0 \\
\hline 0.3 & - & - & - & - & 0.9 & 0.3 & - & - & - & _- & - & - & 21.3 & 1.3 & 99.5 \\
\hline- & 3.0 & - & G. 7 & - & - & - & 3.0 & - & - & 0.7 & - & - & 11.3 & 9.0 & 100.0 \\
\hline - & - & - & - & - & - & - & - & - & - & - & 2.1 & - & 82.4 & - & 100.7 \\
\hline- & - & - & - & - & - & - & - & - & - & - & 43.0 & - & 43.8 & - & 100.0 \\
\hline
\end{tabular}

B-2 and B-3, Eopleistocene (Menap, Waal, Eburon); Cores 35 to 57 - Units B-4-a, b, c, Pliocene; Cores 58 to 79 - Units B-4-d, e, B-5, Miocene.

${ }^{\mathrm{a}}$ Data of V. P. Kazakova.

heavy subfraction consists almost entirely of iron sulfides, but Sample 19-2, 0-16 cm, contains magnetite.

Pliocene deposits are represented mainly by carbonate and clay varves (Cores 35 to 57). Their coarse-silt mineral composition differs from the Pleistocene deposits chiefly in the amphibole and mica marked decrease and increase in the opaque mineral content. Among the latter magnetite or black opaques, or leucoxene, or iron hydroxides are predominant. Authigenic opaque minerals are characterized by abundant iron sulfides which make up more than $80 \%$ in a number of interbeds. Barite occurs sporadically in insignificant quantities.

In heavy subfractions, in addition to opaque minerals, epidotes and garnets are usually dominant. In some samples (36, CC and $43, \mathrm{CC})$, hornblende is also present in notable amounts. The amphibole-epidotegarnet assemblage, so characteristic of Pleistocene deposits, is found only in one interbed $(36, \mathrm{CC})$.
Diatomaceous clays and marls encountered in Cores 41,43 , and 44 (Table 3) are mineralogically heterogeneous. They are enriched either in opaque clastic minerals (magnetite or leucoxene) or in iron sulfides. In one sample $(43-1,0-13 \mathrm{~cm})$ fish teeth and bones are relatively abundant, which suggests a slow sedimentation rate. In Sample 43-3, 112-126 cm, where clastic minerals are more abundant, epidotes, micas, and garnets are the most prominent minerals, excluding opaques.

The heavy mineral composition in diatomaceous clays and marls occurring in different parts of the Pliocene section is variable. In a sample from the lower part of the section $(56-1,95-105 \mathrm{~cm})$, the heavy subfraction is represented almost entirely by black opaque minerals $(76.08 \%)$. The remainder of the heavy subfraction is characterized by sphene, rutile, garnets, and epidotes; amphiboles and pyroxenes are entirely absent. In Sample 46-3, 1-10 cm, epidotes and iron 
TABLE 4

Mineral Composition of Heavy (sp.w.>2.9) Subfraction $0.1-0.05 \mathrm{~mm}$, Site 381, Leg 42B

\begin{tabular}{|c|c|c|c|c|c|c|c|c|c|c|c|c|c|c|c|c|}
\hline $\begin{array}{c}\text { Sample } \\
\text { (Interval in cm) }\end{array}$ & $\begin{array}{l}\text { Content of } \\
\text { Heavy Sub- } \\
\text { fraction (\%) }\end{array}$ & 1 & 2 & 3 & 4 & 5 & 6 & 7 & 8 & 9 & 10 & 11 & 12 & 13 & 14 & 15 \\
\hline $1-3,020$ & 6.8 & 9.6 & 4.5 & 2.3 & 4.0 & 12.5 & - & 14.8 & - & 2.3 & 4.0 & 2.8 & - & 1.7 & 1.7 & 8.5 \\
\hline $3-2,55-75$ & 6.5 & 5.3 & 2.3 & 43.9 & 6.6 & - & 0.3 & 9.2 & 0.3 & 17.8 & - & - & - & 0.7 & - & 5.6 \\
\hline $4-2,115-140$ & 4.1 & 6.2 & 0.8 & 4.6 & 6.2 & 8.4 & - & 4.3 & 4.3 & 14.9 & 23.8 & 1.9 & 0.3 & 0.3 & 0.3 & 2.7 \\
\hline $5-3,115-135$ & 15.8 & 38.0 & 1.7 & 15.5 & 3.0 & - & - & 4.0 & 0.3 & 8.9 & - & - & - & - & - & 1.3 \\
\hline $8-3,126-140$ & 4.0 & 3.5 & 2.4 & 4.0 & 3.0 & 12.6 & 0.3 & 5.1 & 1.1 & 9.4 & 16.6 & 1.1 & - & 0.3 & 0.8 & 2.4 \\
\hline $9, \mathrm{CC}^{\mathrm{a}}$ & - & 3.1 & - & 33.4 & 10.3 & 2.6 & - & 22.0 & - & - & - & 0.9 & 1.4 & - & - & 12.5 \\
\hline $10, \mathrm{CC}^{\mathrm{a}}$ & - & 6.8 & - & - & - & - & - & 2.6 & - & - & - & 0.8 & - & - & - & 1.7 \\
\hline $11-2,0-15$ & 5.7 & 9.0 & 2.0 & 4.0 & 7.0 & 6.6 & - & 10.0 & 2.7 & 18.7 & 12.7 & 0.7 & - & 1.0 & 0.3 & 5.3 \\
\hline $13-3,90-105$ & 6.3 & 20.5 & 6.1 & 0.7 & 7.4 & 6.1 & 3.0 & 13.8 & 0.3 & 22.2 & - & 0.7 & - & 0.3 & 0.3 & 7.4 \\
\hline $13, \mathrm{CC}^{\mathrm{a}}$ & - & 2.5 & - & 4.0 & 20.5 & 2.5 & - & 30.2 & - & 0.8 & - & 0.8 & _- & 1.5 & 0.5 & 12.2 \\
\hline $14, \mathrm{CC}^{\mathrm{a}}$ & - & - & - & 3.2 & 7.6 & - & - & 26.6 & - & - & - & 2.4 & - & - & - & 6.4 \\
\hline $16-5,0-20$ & 6.6 & 50.2 & 3.6 & 3.3 & 3.3 & 0.3 & - & 10.9 & 1.3 & 13.0 & - & 0.7 & - & 1.0 & 0.3 & 5.9 \\
\hline $19, \mathrm{CC}^{\mathrm{a}}$ & - & 1.3 & - & 51.1 & 12.3 & 2.3 & - & 11.7 & 0.5 & 1.3 & - & 0.5 & - & - & 0.3 & 3.3 \\
\hline $22-1,40-55$ & 7.5 & 8.1 & 1.0 & 1.0 & 0.7 & - & - & 4.2 & 1.0 & 1.6 & 1.3 & - & - & - & - & 0.7 \\
\hline $26-3,40-50$ & 6.2 & 35.0 & 2.6 & 3.6 & 0.3 & 0.7 & - & 11.0 & 1.0 & 1.6 & 2.3 & 0.3 & - & 0.7 & 0.7 & 1.3 \\
\hline $26, \mathrm{CC}^{\mathrm{a}}$ & - & 1.8 & - & 2.3 & 0.9 & - & - & - & - & - & - & - & - & - & - & 1.4 \\
\hline $28-3,70-85$ & 3.7 & 1.0 & 0.3 & - & - & - & - & 9.6 & - & 6.3 & - & - & - & 1.0 & - & 1.0 \\
\hline $31, \mathrm{CC}^{\mathrm{a}}$ & - & 1.1 & - & 2.5 & 0.5 & - & - & 1.4 & - & - & - & 0.3 & - & - & - & 0.5 \\
\hline $32-1,31-44$ & 4.5 & 7.5 & 0.9 & 10.7 & 0.3 & 0.9 & - & 3.5 & 0.3 & 0.3 & 0.3 & 0.3 & - & - & - & 0.3 \\
\hline $37-2,30-40$ & 4.5 & 1.5 & - & 0.3 & - & - & - & 6.9 & 0.6 & 0.3 & - & - & - & 1.5 & 0.6 & 0.6 \\
\hline $48-6,110-120$ & 0.9 & 3.6 & 5.1 & 2.3 & - & - & - & 38.0 & 11.3 & 18.0 & - & 0.3 & - & 5.5 & 0.3 & 3.2 \\
\hline $51-6,73-83$ & 1.8 & 1.3 & 3.5 & 4.8 & - & - & 0.3 & 9.2 & 9.9 & 49.4 & - & - & - & 1.3 & - & 0.3 \\
\hline $53-3,125-135$ & 1.6 & 8.7 & 5.8 & 22.0 & 0.3 & - & 0.3 & 29.1 & 3.6 & 11.7 & 2.3 & 0.7 & - & 2.9 & 0.7 & 6.2 \\
\hline $54-4,3-13$ & 1.7 & 4.8 & 6.0 & 29.2 & - & - & - & 28.9 & 5.4 & 10.5 & - & - & - & 2.9 & 1.0 & 5.1 \\
\hline
\end{tabular}

Note: 1 , opaque black; 2 , leucoxene; 3 , limonite, hydrogoethite; 4 , hornblende; 5 , actinolite-tremolite; 6 , alkalic amphiboles; 7 , epidotezoisite; 8 , biotite; 9 , chlorite; 10 , muscovite; 11 , zircon; 12 , apatite; 13 , sphene; 14 , rutile; 15 , garnet; 16 , tourmaline; 17 , staurolite; 18 , chloritoid; 19 , disthene (kyanite); 20 , sillimanite; 21 , andalusite; 22 , rare (brukite, vollastonite, etc.); 23 , clinopyroxene; 24 , orthopyro-

hydroxides are dominant, followed by carbonates, micas, garnets, etc.; amphiboles are found only in single grains.

A metamorphic assemblage of clastic minerals (epidote, garnet, andalusite or sillimanite, mica) is found in carbonate varves poor in organic matter (51-4, $34-50 \mathrm{~cm} ; 52-2,0-12 \mathrm{~cm} ; 56-1,95-105 \mathrm{~cm})$. In some layers $(52-2,0-12 \mathrm{~cm})$ high contents of titaniumcontaining (sphene, rutile, brukite, anatase) and opaque clastic minerals are detected. Some patterns of carbonate varves are enriched in fish teeth and bones $(51-4,34-50 \mathrm{~cm})$.

Thus, during Pliocene time sediments were delivered to the Site 380 area from surrounding lands underlain by metamorphic rock assemblages (such as the Dobrudga and Bosphorus regions). Only during some periods did they come from the Danube.

The Miocene section (Cores 58 to 79) is mineralogically highly heterogeneous. The main part of the heavy subfractions is the iron sulfides. Epidote, the contents of which range from $1.8 \%$ to $17.3 \%$, is the most characteristic clastic mineral. The coarse-silt fraction of fine silty muds $(62-2,0-5 \mathrm{~cm})$ is notably enriched in ilmenite and other black opaque non-magnetic minerals. Garnet, zircon, sometimes staurolite, and some other accessories are significant. Very low mica contents are typical.

On the basis of this heavy mineral composition, the principal sources supplying the area during Miocene time were most likely located in the western and southern parts of the drainage area.

\section{Site 381}

The lithological and mineral composition of Holocene and upper Pleistocene deposits in the Site 381 area is known from previous studies (Station 4754-5; Table 5). The amphibole-epidote-mica-zircon assemblage is characteristic of upper Holocene muds. In middle Holocene sediments two assemblages alternate, one containing mica-epidote-amphibolezircon and the other epidote-amphibole-garnet. Both contain considerable contents of zircon, sphene, rutile, and other minerals. Significant amounts of black opaques occur throughout the Holocene sediments sequence, but in single interbeds iron sulfides dominate.

In upper Würm muds the epidote-amphibole-garnet assemblage occurs, supplemented in some interbeds with significant quantities of micas. Zircon and titanium-containing minerals constantly occur. High garnet contents (up to $18.3 \%$ ) are characteristic of the lower part of the section, black opaque minerals are abundant and, in one interbed, iron sulfides are present. Pyroxene content throughout the core is low.

Although the heavy mineral composition of the heavy mineral group is most like that contributed by the Danube, some of the mineral assemblages most probably reflect sorting by transporting currents; in part, the heavy mineral assemblages represent the loads delivered from the Bosphorus petrographic province.

Lower Pleistocene deposits of Site 381 are represented by terrigenous clay and muds, mainly poor in organic matter. They occur as turbidite layers. The heavy mineral composition in clays and muds is 
TABLE 4 - Continued

\begin{tabular}{rrlllllllllllllll}
\hline 16 & 17 & 18 & 19 & 20 & 21 & 22 & 23 & 24 & 25 & 26 & 27 & 28 & 29 & 30 & Total (\%) \\
\hline 1.1 & - & - & - & 0.6 & - & - & 5.7 & 1.7 & 5.1 & 0.6 & - & - & 10.8 & 4.5 & 98.8 \\
0.3 & - & - & - & - & - & - & 0.7 & 0.7 & - & 1.3 & - & - & 3.3 & 0.7 & 99.0 \\
1.4 & - & - & - & 0.8 & 0.3 & - & 2.4 & 0.8 & - & 0.8 & - & 0.5 & 10.5 & 3.3 & 99.8 \\
0.3 & - & - & - & - & - & - & 0.7 & - & - & 1.0 & - & - & 24.4 & - & 99.1 \\
0.3 & 0.3 & 0.3 & 0.3 & 0.3 & - & - & 1.6 & 0.6 & 1.3 & 1.9 & - & - & 24.1 & 6.7 & 100.3 \\
0.3 & 0.9 & - & - & - & - & - & 4.9 & 1.7 & - & - & 0.3 & - & 5.7 & - & 100.0 \\
- & - & - & - & - & - & - & 1.7 & - & - & - & - & - & 77.0 & 9.4 & 100.0 \\
0.3 & - & - & 1.0 & - & 0.7 & 0.3 & 1.0 & 0.3 & - & 1.0 & - & - & 14.0 & 1.0 & 99.6 \\
1.7 & - & - & 0.3 & - & - & 0.6 & 1.0 & - & - & 0.7 & - & - & 7.1 & - & 100.2 \\
0.5 & 0.3 & - & 0.5 & - & - & - & 2.0 & 0.3 & - & - & 5.0 & - & 9.1 & 6.8 & 100.0 \\
- & - & - & - & - & - & - & 0.8 & - & - & - & 0.4 & - & 52.6 & - & 100.0 \\
1.0 & - & - & - & 0.7 & 1.3 & - & - & - & - & - & - & - & 2.6 & 0.7 & 100.1 \\
0.3 & - & - & 0.3 & - & - & - & 3.8 & - & - & - & 3.3 & - & 4.6 & 3.1 & 100.0 \\
- & - & - & - & - & - & - & - & - & - & 1.6 & - & - & 76.2 & - & 97.4 \\
- & - & - & 0.3 & - & 0.3 & 0.6 & - & - & - & 0.3 & - & - & 36.8 & - & 99.4 \\
- & - & - & - & - & - & - & 1.8 & - & - & - & 0.5 & - & 87.6 & 3.7 & 100.0 \\
- & - & - & - & - & 0.3 & - & - & - & - & 2.7 & - & - & 77.8 & - & 100.0 \\
- & - & - & - & - & - & - & 0.5 & - & - & - & - & - & 92.1 & 1.1 & 100.0 \\
- & - & - & - & - & 0.3 & - & 1.2 & - & 0.9 & 0.9 & - & 0.3 & 66.4 & 4.7 & 100.0 \\
- & - & - & - & - & - & - & - & - & - & 1.5 & - & - & 86.3 & - & 100.1 \\
0.3 & - & - & 0.9 & - & 3.5 & - & - & - & - & 0.6 & - & - & 6.8 & 0.3 & 100.0 \\
- & - & - & - & - & 2.2 & - & - & - & - & 5.8 & - & - & 9.6 & 1.9 & 99.5 \\
0.7 & - & - & - & - & 1.0 & 0.7 & - & - & - & 1.9 & - & - & 0.7 & - & 99.3 \\
- & - & - & 0.3 & - & 2.5 & 0.3 & - & - & - & 0.6 & - & - & 2.2 & - & 99.7 \\
\hline
\end{tabular}

xene; 25 , volcanic glass, ash; 26 , carbonates; 27 , barite; 28 , glauconite; 29 , sulfides; 30 , rock fragments, etc.; Cores 1 to 17 - Unit 3, Pleistocene; Cores 18 to 19 - Unit 4, Eopleistocene; Cores 19 to 38 - Units 5 to 7 , Pliocene; Cores 39 to 54 - Units 8 to 11 , Miocene.

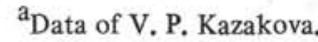

similar to corresponding sediments of Site $380 \mathrm{~A}$; there the alternation of three principal clastic mineral assemblages is observed: (1) an epidote-amphibolegarnet assemblage; (2) an amphibole-epidote-garnetmica assemblage; and (3) a mica-amphibole-epidotegarnet one. High contents of garnet (up to $12.5 \%$ ) are characteristic of some interbeds, zircon, tourmaline, and clinopyroxenes, which make up between $4.9 \%$ and $5.7 \%$ in some interbeds, are always present. Opaque clastic minerals are represented by large quantities of magnetite in some layers, and by iron hydroxides in others. Authigenic minerals are characterized by the ubiquitous presence of iron sulfides, exceeding $70 \%$ in some interbeds. Barite occurs sporadically.

Pliocene units are lithologically heterogeneous. Mineralogy studies were carried out for single interbeds of each unit. As shown in Table 4, Pliocene sediments differ from those of the Pleistocene mainly by the marked decrease in amphiboles (as little as single grains). The main part of heavy subfractions is sulfides. Clastic minerals are dominated by epidote; garnet consistently occurs in insignificant quantities, and zircon, sphene, and rutile are more rare. High concentrations of opaque minerals are typical of Pliocene deposits. In some interbeds $(26-3,40-50 \mathrm{~cm})$ magnetite is abundant.

In the Miocene samples (Units 9 to 11), the coarsesilt fraction differs from those of Pliocene first of all in the low sulfide contents and in increased amounts of clastic minerals. In particular there is a great abundance of epidote, micas (mainly green and biotite), garnet and sphene.

The sources of this terrigenous material during Pliocene-Miocene time were undoubtedly the same as for Site 380/380A.

\section{SUMMARY}

The study of the coarse-silt fraction terrigenous minerals in various lithological units of late Cenozoic deposits in the Black Sea reveals some features of terrigenous supply and sedimentation. In the eastern part of the basin, repeated changes in mineral assemblages in Pleistocene deposits cover not only large lithostratigraphical units but also smaller intervals. In some cases, the sediments were supplied by a southern drainage area, whereas in other cases, the sources lay to the east and north.

From the earliest Pleistocene approximately up to late Riss the main delivery into the Hole 379A area came from the Caucasian drainage system, where metamorphic rock formations were being eroded. During later Pleistocene time the southern drainage area (eastern and western Pont) began to play a significant role, as evidenced by high contents of clinopyroxene occurring with hornblende and epidotes.

The influence of the northern area supply is obviously reflected in late and early Riss time. Possibly, at that time, the mouth of the Don River reached the edge of the Black Sea outer shelf, suggesting in turn, a much lower sea level.

In the southwestern part of the Black Sea, judging from the heavy mineral composition of Sites 380/380A and 381 , terrigenous sediments were principally supplied by northern, northwestern, and southern sources. The Pleistocene mineral assemblages of both glacial and interglacial units are varied and alternate repeatedly, suggesting that the main source, the Danube River, emptied alternately nearer to and farther from the drilling area. This reflects sea level fluctuations which also greatly influenced erosional 
TABLE 5

Heavy Minerals (sp.w. >2.9) of Fraction 0.1-0.05 mm in Holocene and Late Pleistocene Sediments From Drilling Areas

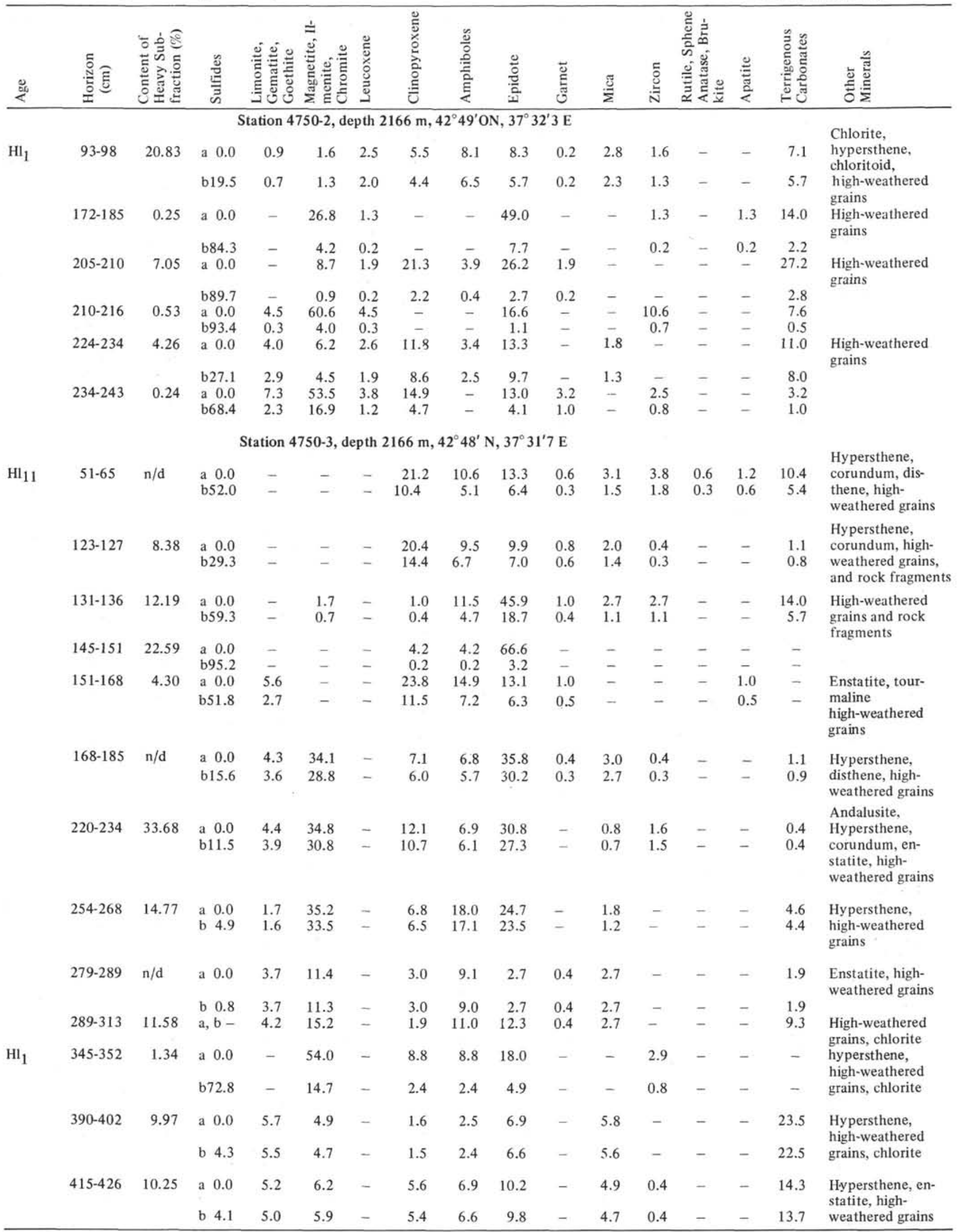


TABLE 5 - Continued

\begin{tabular}{|c|c|c|c|c|c|c|c|c|c|c|c|c|c|c|c|c|c|}
\hline 品 & 돌로일 & 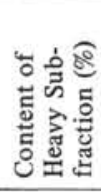 & & 苋 & 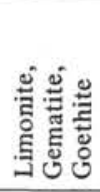 & 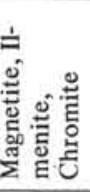 & 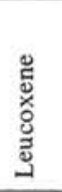 & 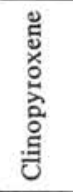 & $\begin{array}{l}\frac{0}{0} \\
00 \\
\frac{0}{0} \\
\text { है }\end{array}$ & 芯 & 志 & $\stackrel{\Xi}{\Sigma}$ & 芯 & 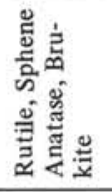 & 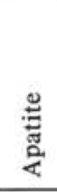 &  & 总 \\
\hline \multirow[t]{6}{*}{$\mathrm{Hl}_{1}$} & $428-435$ & 4.27 & & $\begin{array}{l}0.0 \\
6.8\end{array}$ & $\begin{array}{l}10.7 \\
10.0\end{array}$ & $\begin{array}{l}32.0 \\
29.8\end{array}$ & - & $\begin{array}{l}0.6 \\
0.6\end{array}$ & $\begin{array}{l}3.3 \\
3.1\end{array}$ & $\begin{array}{l}48.0 \\
44.7\end{array}$ & - & $\begin{array}{l}1.6 \\
1.5\end{array}$ & $\begin{array}{l}- \\
-\end{array}$ & - & - & $\begin{array}{l}3.0 \\
2.8\end{array}$ & $\begin{array}{l}\text { High-weathered } \\
\text { grains, chlorite }\end{array}$ \\
\hline & $480-494$ & 14.01 & $\begin{array}{l}\mathrm{a} \\
\mathrm{b}\end{array}$ & $\begin{array}{l}0.0 \\
5.0\end{array}$ & $\begin{array}{l}12.8 \\
12.2\end{array}$ & $\begin{array}{l}25.6 \\
24.3\end{array}$ & - & $\begin{array}{l}10.7 \\
10.2\end{array}$ & $\begin{array}{l}5.8 \\
5.5\end{array}$ & $\begin{array}{l}33.9 \\
32.2\end{array}$ & - & $\begin{array}{l}1.9 \\
1.8\end{array}$ & $\begin{array}{l}0.7 \\
0.7\end{array}$ & $\begin{array}{l}0.4 \\
0.4\end{array}$ & - & $\begin{array}{l}2.6 \\
2.5\end{array}$ & $\begin{array}{l}\text { Hypersthene, } \\
\text { high-weathered } \\
\text { grains, chloritoid }\end{array}$ \\
\hline & $500-507$ & 3.00 & & $\begin{array}{r}0.0 \\
94.4\end{array}$ & - & $\begin{array}{r}58.9 \\
3.3\end{array}$ & - & - & - & $\begin{array}{r}37.5 \\
2.1\end{array}$ & - & - & - & - & - & - & \\
\hline & $579-593$ & 5.14 & & $\begin{array}{l}0.0 \\
2.4\end{array}$ & $\begin{array}{l}9.8 \\
9.6\end{array}$ & $\begin{array}{l}18.4 \\
18.0\end{array}$ & $\begin{array}{l}- \\
-\end{array}$ & $\begin{array}{l}18.8 \\
18.3\end{array}$ & $\begin{array}{l}3.8 \\
3.7\end{array}$ & $\begin{array}{l}16.8 \\
16.4\end{array}$ & $\overline{-}$ & $\begin{array}{l}6.9 \\
6.7\end{array}$ & $\begin{array}{l}1.2 \\
1.2\end{array}$ & - & - & $\begin{array}{l}4.1 \\
4.0\end{array}$ & $\begin{array}{l}\text { Hypersthene } \\
\text { high-weathered } \\
\text { grains, chlorite }\end{array}$ \\
\hline & $624-645$ & 8.23 & $\begin{array}{l}\mathrm{a} \\
\mathrm{b}\end{array}$ & $\begin{array}{l}0.0 \\
0.5\end{array}$ & $\begin{array}{l}1.9 \\
1.9\end{array}$ & $\begin{array}{l}17.0 \\
16.9\end{array}$ & $\begin{array}{l}3.3 \\
3.3\end{array}$ & $\begin{array}{l}12.5 \\
12.4\end{array}$ & $\begin{array}{l}11.4 \\
11.4\end{array}$ & $\begin{array}{l}37.8 \\
37.6\end{array}$ & $\begin{array}{l}1.0 \\
1.0\end{array}$ & $\begin{array}{l}1.5 \\
1.5\end{array}$ & $\begin{array}{l}3.3 \\
3.3\end{array}$ & $\begin{array}{l}- \\
-\end{array}$ & $\begin{array}{l}- \\
-\end{array}$ & $\begin{array}{l}1.0 \\
1.0\end{array}$ & $\begin{array}{l}\text { Hypersthene, } \\
\text { high-weathered } \\
\text { grains, chlorite }\end{array}$ \\
\hline & $646-653$ & 5.00 & a & - & 7.0 & 12.0 & 3.0 & 8.2 & 4.0 & 20.9 & - & 6.5 & 0.5 & - & - & 20.9 & $\begin{array}{l}\text { Hypersthene, } \\
\text { high-weathered } \\
\text { grains, chlorite }\end{array}$ \\
\hline $\mathrm{w}_{11}(?)$ & $653-677$ & 3.25 & & $\begin{array}{l}0.0 \\
2.4\end{array}$ & $\begin{array}{l}2.6 \\
2.5\end{array}$ & $\begin{array}{l}28.8 \\
28.1\end{array}$ & $\begin{array}{l}5.5 \\
5.4\end{array}$ & $\begin{array}{l}18.1 \\
17.7\end{array}$ & $\begin{array}{l}3.6 \\
3.5\end{array}$ & $\begin{array}{l}32.1 \\
31.3\end{array}$ & $\begin{array}{l}0.8 \\
0.8\end{array}$ & $\begin{array}{l}0.4 \\
0.4\end{array}$ & $\begin{array}{l}- \\
-\end{array}$ & $\begin{array}{ll}- & \\
-\end{array}$ & $\begin{array}{l}- \\
-\end{array}$ & $\begin{array}{l}0.8 \\
0.8\end{array}$ & $\begin{array}{l}\text { High-weathered } \\
\text { grains, chlorite }\end{array}$ \\
\hline \multicolumn{18}{|c|}{ Station $4754-5$, depth $1193 \mathrm{~m}, 41^{\circ} 35^{\prime} 3 \mathrm{~N}, 29^{\circ} 21^{\prime} 6 \mathrm{E}$} \\
\hline $\mathrm{Hl}_{111}$ & $71-82$ & 36.66 & & $\begin{array}{r}0.0 \\
97.5\end{array}$ & - & $\begin{array}{r}20.0 \\
0.5\end{array}$ & $\begin{array}{l}- \\
-\end{array}$ & $\begin{array}{ll}- & \\
-\end{array}$ & $\begin{array}{l}8.0 \\
0.2\end{array}$ & $\begin{array}{r}20.0 \\
0.5\end{array}$ & - & $\begin{array}{r}12.0 \\
0.3\end{array}$ & $\begin{array}{l}8.0 \\
0.2\end{array}$ & - & $\begin{array}{l}- \\
-\end{array}$ & $\begin{array}{r}20.0 \\
0.5\end{array}$ & Andalusite \\
\hline \multirow[t]{4}{*}{$\mathrm{Hl}_{11}$} & $110-125$ & 2.85 & & $\begin{array}{r}0.0 \\
40.2\end{array}$ & $\begin{array}{l}5.7 \\
3.4\end{array}$ & $\begin{array}{l}32.9 \\
19.7\end{array}$ & - & $\begin{array}{l}2.8 \\
1.7\end{array}$ & $\begin{array}{l}17.0 \\
10.2\end{array}$ & $\begin{array}{l}17.0 \\
10.2\end{array}$ & $\begin{array}{l}4.2 \\
2.5\end{array}$ & $\begin{array}{l}5.7 \\
3.4\end{array}$ & $\begin{array}{l}1.5 \\
0.9\end{array}$ & - & $\begin{array}{l}- \\
-\end{array}$ & $\begin{array}{l}1.3 \\
0.8\end{array}$ & $\begin{array}{l}\text { Andalusite } \\
\text { tourmaline, } \\
\text { clastic rocks }\end{array}$ \\
\hline & $170-185$ & $\mathrm{n} / \mathrm{d}$ & $\begin{array}{l}\mathrm{a} \\
\mathrm{b}\end{array}$ & $\begin{array}{l}0.0 \\
9.2\end{array}$ & $\begin{array}{r}10.1 \\
9.2\end{array}$ & $\begin{array}{l}8.1 \\
7.4\end{array}$ & $\begin{array}{l}6.0 \\
5.5\end{array}$ & - & $\begin{array}{l}6.0 \\
5.5\end{array}$ & $\begin{array}{r}10.1 \\
7.4\end{array}$ & - & $\begin{array}{l}34.5 \\
31.3\end{array}$ & $\begin{array}{l}4.1 \\
3.7\end{array}$ & $\begin{array}{l}2.0 \\
1.8\end{array}$ & - & $\begin{array}{l}16.3 \\
14.8\end{array}$ & Rock fragments \\
\hline & $230-245$ & 1.57 & $\begin{array}{l}\mathrm{a} \\
\mathrm{b}\end{array}$ & $\begin{array}{l}0.3 \\
0.3\end{array}$ & $\begin{array}{l}3.4 \\
3.4\end{array}$ & $\begin{array}{l}30.4 \\
30.3\end{array}$ & $\begin{array}{l}7.7 \\
7.7\end{array}$ & $\begin{array}{l}2.0 \\
2.0\end{array}$ & $\begin{array}{l}6.3 \\
6.3\end{array}$ & $\begin{array}{l}19.0 \\
18.9\end{array}$ & $\begin{array}{l}7.2 \\
7.2\end{array}$ & $\begin{array}{l}3.8 \\
3.8\end{array}$ & $\begin{array}{l}2.5 \\
2.5\end{array}$ & $\begin{array}{l}2.3 \\
2.3\end{array}$ & $\overline{-}$ & $\begin{array}{l}7.5 \\
7.5\end{array}$ & $\begin{array}{l}\text { Andalusite, tour- } \\
\text { maline, chlorite, } \\
\text { sillimanite, rock } \\
\text { fragments }\end{array}$ \\
\hline & $262-270$ & 0.27 & & $\begin{array}{l}0.0 \\
3.6\end{array}$ & $\begin{array}{l}2.4 \\
2.3\end{array}$ & $\begin{array}{l}31.4 \\
30.3\end{array}$ & $\begin{array}{l}7.8 \\
7.5\end{array}$ & $\begin{array}{l}0.8 \\
0.8\end{array}$ & $\begin{array}{l}5.6 \\
5.4\end{array}$ & $\begin{array}{l}11.5 \\
11.1\end{array}$ & $\begin{array}{l}12.0 \\
11.6\end{array}$ & $\begin{array}{l}2.2 \\
2.1\end{array}$ & $\begin{array}{l}5.7 \\
5.5\end{array}$ & $\begin{array}{l}4.6 \\
4.4\end{array}$ & $\begin{array}{l}- \\
-\end{array}$ & $\begin{array}{l}6.9 \\
6.7\end{array}$ & $\begin{array}{l}\text { Andalusite, tour- } \\
\text { maline, ortho- } \\
\text { rhombic pyrox- } \\
\text { enes }\end{array}$ \\
\hline \multirow[t]{3}{*}{$w_{11}$} & $482-500$ & $\mathrm{n} / \mathrm{d}$ & & $\begin{array}{r}0.0 \\
64.2\end{array}$ & $\begin{array}{l}1.7 \\
0.6\end{array}$ & $\begin{array}{l}5.6 \\
2.0\end{array}$ & $\begin{array}{l}0.8 \\
0.3\end{array}$ & $\begin{array}{l}2.2 \\
0.8\end{array}$ & $\begin{array}{r}11.2 \\
4.0\end{array}$ & $\begin{array}{r}13.7 \\
4.9\end{array}$ & $\begin{array}{l}7.3 \\
2.6\end{array}$ & $\begin{array}{r}10.0 \\
3.6\end{array}$ & $\begin{array}{l}2.2 \\
0.8\end{array}$ & $\begin{array}{l}0.8 \\
0.3\end{array}$ & $\overline{-}$ & $\begin{array}{l}38.0 \\
13.6\end{array}$ & $\begin{array}{l}\text { Andalusite, tour- } \\
\text { maline, sillman- } \\
\text { ite, rock frag- } \\
\text { ments }\end{array}$ \\
\hline & $600-611$ & 0.12 & & $\begin{array}{r}0.0 \\
14.1\end{array}$ & $\begin{array}{l}2.0 \\
1.7\end{array}$ & $\begin{array}{l}38.3 \\
32.9\end{array}$ & $\begin{array}{l}5.9 \\
5.1\end{array}$ & $\begin{array}{l}3.6 \\
3.1\end{array}$ & $\begin{array}{l}9.7 \\
8.3\end{array}$ & $\begin{array}{r}11.4 \\
9.8\end{array}$ & $\begin{array}{r}10.9 \\
9.4\end{array}$ & $\begin{array}{l}0.5 \\
0.4\end{array}$ & $\begin{array}{l}2.8 \\
2.4\end{array}$ & $\begin{array}{l}2.0 \\
1.7\end{array}$ & $\begin{array}{l}- \\
-\end{array}$ & $\begin{array}{l}2.2 \\
1.9\end{array}$ & $\begin{array}{l}\text { Andalusite, tour- } \\
\text { maline, disthene, } \\
\text { sillimanite }\end{array}$ \\
\hline & $692-720$ & 0.18 & $\begin{array}{l}\mathrm{a} \\
\mathrm{b}\end{array}$ & $\begin{array}{l}0.0 \\
0.7\end{array}$ & $\begin{array}{l}1.1 \\
1.1\end{array}$ & $\begin{array}{l}37.0 \\
36.7\end{array}$ & $\begin{array}{l}6.3 \\
6.3\end{array}$ & $\begin{array}{l}3.9 \\
3.9\end{array}$ & $\begin{array}{l}5.9 \\
5.9\end{array}$ & $\begin{array}{l}12.3 \\
12.2\end{array}$ & $\begin{array}{l}18.3 \\
18.2\end{array}$ & $\begin{array}{l}6.1 \\
6.1\end{array}$ & $\begin{array}{l}1.1 \\
1.1\end{array}$ & $\begin{array}{l}2.9 \\
2.9\end{array}$ & - & $\begin{array}{l}0.3 \\
0.3\end{array}$ & $\begin{array}{l}\text { Disthene, hyper- } \\
\text { sthene }\end{array}$ \\
\hline
\end{tabular}

Note: $\mathrm{a}=$ the content of sulfide-free heavy subfraction; $\mathrm{b}=$ the content of heavy subfraction including sulfides. $\mathrm{n} / \mathrm{d}$ - not determined.

processes in the Dobrudga from whence came the products of metamorphic rock destruction.

Loads supplied by the Dobrudga rivers were of significant importance during Pliocene-Miocene sedimentation, as is supported by the widespread occurrence of metamorphic mineral assemblages in these deposits (Sites $380 \mathrm{~A}$ and 381). High contents of opaque clastic minerals indicate comparatively nearby sources. On the basis of the heavy mineral composition in these sediments, the Danube either did not exist at that time, which is in conformity to the shore studies of Onchesku (1960), who discovered that during Pliocene time the Outer-Carpathian lake was located at the present position of the Danube's modern mouth. At 
that time, the Dobrudga was uplifted and extended far time was intensified, not only by uplifting, but also by a to the east, occupying almost all of the area presently comprising the recent Black Sea shelf. Erosion at that much more humid climate.

\section{REFERENCES}

Müller, G. and Stoffers, P., 1974. Mineralogy and petrology of the Black Sea basin sediments. In Degens, E.T. and
Ross, D.A. (Eds.), The Black Sea: its geology, chemistry and biology: AAPG Mem. 20, p. 200-248.

Onchesku, N., 1960. Geologiya Rumynskoi Narodnoi Respubliki (Geology of People's Republic of Romania): Izd. Inostr. Lit., Moscow, Izd. "Meridiany," Bucharest, p. 520 .

Paffengoltz, K.N., 1959. Geologicheskiy ocherk Kavkaza (The geological feature of the Caucasus): Izd. AN Armyanskoi SSR, Erevan, p. 506.

Trimonis, E.S., 1972. Sovremennoe osadkoobrazovanie v Chernom more (Modern sedimentation in the Black Sea): Kand. Diss., Moscow. 